\title{
Contracting Institutions and Vertical Integration: Evidence from China's Manufacturing Firms
}

\author{
Julan $\mathrm{Du}^{\mathrm{a}}$, Yi Lu ${ }^{\mathrm{b}}$, and Zhigang Tao ${ }^{\mathrm{c},}$ \\ a Chinese University of Hong Kong \\ b National University of Singapore \\ ${ }^{\mathrm{c}}$ University of Hong Kong \\ First Version: April 2010 \\ This Version: October 2011
}

\begin{abstract}
The existing studies on vertical integration focus on factors at the transaction parties' level, such as asset specificity and contractual incompleteness. What is overlooked is the quality of the underlying institutions, in particular, contracting institutions. In this paper, using a World Bank data set of manufacturing firms in China, we find that poorer contracting institutions cause firms to be more vertically integrated. Our results are robust to various checks, especially the inclusion of the quality of financial institutions.
\end{abstract}

Keywords: Contracting Institutions, Vertical Integration, Legal Origins

JEL Codes: L23, D23, P26, K12

* We thank the editor and anonymous reviewers for very helpful suggestions and advice. Financial support from the National University of Hong Kong, the University of Hong Kong and Hong Kong Research Grants Council is acknowledged. 


\section{Introduction}

The choice of vertical boundary is a key decision for firms, as it has been found to affect firm performance and consequently economic growth (Novak and Stern, 2008; Forbes and Lederman, 2010). Indeed, this issue has been extensively studied since Coase's seminal work in 1937, with a focus on the relationship specificity of investments and the degree of contractual incompleteness. In recent years, researchers have begun to pay attention to the impacts of institutional quality on the organization of production. Khanna and Palepu (1997, 2000) notice the prevalence of large and highly vertically integrated firms in developing countries such as India. By studying Indian business groups, they find that affiliates of business groups often outperform unaffiliated firms. They suggest that the poorly functioning market-supporting institutions in India make the benefits of business groups dominate the costs of group affiliation under certain circumstances. Although their studies are related to vertical integration, the authors did not explicitly examine the impacts of institutions, particularly contracting institutions, on vertical integration in developing countries.

In this paper, using a cross-region data set from the world's largest developing economy, China, we aim at identifying the direct impact of contracting institutions on vertical integration. ${ }^{1}$ Meanwhile, following Acemoglu, Johnson, and Mitton (2009), and Macchiavello (2010a, 2010b), we also investigate how contracting institutions may interact with financial institutions in determining the vertical boundary.

Our empirical analysis uses the data of a World Bank survey of 1,566 firms located in 18 cities and 9 manufacturing industries in China. China offers an ideal setting in which to study the impacts of the quality of contracting institutions on vertical integration, because there exist substantial variations in the de facto quality of contracting institutions across regions in China as a result of substantial disparities in economic and institutional development (e.g., Du, Lu and Tao, 2008; World Bank, 2008; Lu and Tao, 2009). ${ }^{2}$ Specifically, we measure the quality of contracting institutions as

\footnotetext{
${ }^{1}$ Fan, Huang, Morck, and Yeung (2007) also examines how institutional quality (i.e., contract enforcement, government service, and market development) affects the makeor-buy decision. However, they use data of China's publicly-listed firms, which is not a representative sample in China as these publicly-listed firms are large, vertically-integrated and politically connected. Meanwhile, they do not even control for industry dummies in their estimation, which is found to be important in identifying the impact of contracting institutions on vertical integration (Acemoglu, Johnson, and Mitton, 2009).

${ }^{2}$ For example, in coastal cities, it takes an average of 230 days to resolve an uncomplicated commercial dispute, whereas the corresponding number for Northeastern China is 363 days (World Bank, 2008).
} 
the perceived likelihood that the legal system would uphold contract and property rights in business disputes (e.g., Johnson, McMillan, and Woodruff, 2002; Cull and $\mathrm{Xu}, 2005$ ). Meanwhile, we measure the degree of vertical integration in two ways. One is the ratio of value added to sales, which is the most widely-used measure in the literature (Adelman, 1955; Davies and Morris, 1995; Holmes, 1999). The other is constructed on the basis of the reply to the survey question of how large a proportion of inputs are produced in-house by the firm itself.

Our basic OLS regression results show that the quality of contracting institutions has a direct, specifically, negative and significant, impact on firm vertical integration. However, endogeneity could be a serious concern. For instance, there could be a possibility of reverse causality. Entrepreneurs of vertically integrated firms might have less need for outsourcing intermediate goods, and thus have smaller chances to encounter commercial disputes with their business partners. Then they might have less need to ask for court adjudication; and this lack of experience with court resolution may cause those entrepreneurs to have misperceptions of the quality of contracting institutions based on some stereotypes, which may well result in an underestimation of the impact of contracting institutions. In addition, we could have omitted variable bias. For example, a more capable entrepreneur may on one hand have better connections that help her/him secure better de facto contract enforcement, and on the other hand be capable of managing a more vertically-integrated business. Hence, the lack of control for entrepreneurial capability may again lead to an underestimation of the impact of contracting institutions. To mitigate the potential biases stemming from the endogeneity problem, we conduct a series of econometric analyses and robustness checks.

First, we check whether our results are biased due to some omitted variables. Specifically, we include a list of control variables reflecting the CEO characteristics (such as human capital and political capital) and firm characteristics (such as firm size, firm age, percentage of private ownership, access to bank loans, and degree of computerization) as well as industry and city dummies. Our results remain robust to the inclusion of these controls.

Second, to further deal with the possible endogeneity issue, we use the two-step generalized method of moments (GMM) with two alternative instruments, viz., the average response by other firms located in the same city regarding the quality of contracting institutions, and a dummy variable indicating whether the respective city was administered by the Great Britain in the late Qing Dynasty of Imperial China. The two-step GMM estimation results reinforce our findings that the quality of contracting institutions has a negative impact on vertical integration.

Third, we apply the heterogeneous response method of Rajan and Zin- 
gales (1998). According to Acemoglu, Johnson, and Mitton (2009), the quality of contracting institutions has a greater impact on vertical boundary for firms that are more susceptible to supplier hold-up problems. To proxy a firm's reliance on external suppliers, we use two alternative measures: number of suppliers as in Blanchard and Kremer (1997) and Rajan and Subramanian (2007), and capital intensity as in Acemoglu, Johnson, and Mitton (2009). Our results show that indeed the negative impact of the quality of contracting institutions on vertical integration is greater for firms with more external reliance.

Finally, in further robustness checks, we repeat the analysis using an alternative measure of vertical integration, an alternative measure of the quality of contracting institutions, and three sub-samples of firms (i.e., firms with focused businesses, private firms, and small firms). Again our results remain robust in all these specifications.

Our results point to a fairly robust direct impact of contracting institutions on firm vertical boundary. ${ }^{3}$ As argued by Coase (1937), the decision of vertical boundary hinges upon the external environment, the most important component of which is arguably the institutional quality. Nonetheless, the theoretical prediction of the direct effect of institutions on vertical boundary is ambiguous. ${ }^{4}$ There are two leading theories regarding the vertical boundary of firm: the transaction cost theory (Williamson, 1971, 1985; Klein, Crawford, and Alchian, 1978) and the property rights theory (Grossman and Hart, 1986; Hart and Moore, 1990). According to the transaction cost theory, firms are more likely to be vertically integrated when the market transaction cost is higher. When legal institutions for contract enforcement are weak, transaction costs in arms-length transactions are expected to be high. Given that the transaction cost theory is largely silent about the transaction cost within a firm, it predicts that an improvement in contracting institutions will lead to less vertical integration. In contrast, the property rights theory holds the view that the imperfection of contracting institutions affects both in-house production and arms-length transaction. When a firm deals with an independent input supplier in arms-length transaction, the firm is subject to the supplier's holdup problem. When the input supplier becomes an employee in in-house production in the scenario of vertical integration,

\footnotetext{
${ }^{3}$ Our results differ from those of the existing studies such as Acemoglu, Johnson, and Mitton (2009) primarily because of the lack of regional industry specialization in China and the different approaches to measure vertical integration and contracting institutions. See Section 3 for more detailed discussion.

${ }^{4}$ Instead, Acemoglu, Johnson, and Mitton (2009) and Macchiavello (2010a) find that contracting institutions have an indirect effect on vertical integration through the development of financial institutions (see below for more discussions of these two studies).
} 
the firm still faces the potential contract disputes between the employer and the employee. The resolution of both types of contract disputes is affected by contracting institutions. Hence, the property rights theory produces no clear-cut predictions on how the vertical boundary is affected by the quality of contracting institutions.

However, the prevalence of large firms in developing countries with weak contracting institutions suggests that vertical integration might be able to mitigate transactions costs to some extent. It is likely that the transaction costs arising from the holdup problem between two contracting parties in arms-length transactions are on average more serious than the transaction costs existing between the employer and the employee in in-house production in a vertically integrated firm. In arms-length transactions, in addition to bilateral negotiations, the resolution of the holdup problem relies primarily on external contract enforcement institutions such as legal courts, whereas in vertically integrated firms the owner's residual control rights may mitigate to some extent the transactions costs incurred by the disputes between the employer and the employee. If this is the case, we expect to observe a negative relationship between vertical integration and contracting institutions, and a prevalence of vertically integrated firms in developing countries. In other words, vertical integration is an organizational response to poor contracting institutions. Nonetheless, this organizational response may well involve an excessive degree of vertical integration if we use some country with ideal contracting institutions (such as the U.S.) as a benchmark for comparison. An excessive degree of vertical integration may considerably reduce levels of specialization and lead to efficiency losses. Clearly, in this scenario, policy recommendations for improving contracting institutions are called for, which will eventually enhance economic growth.

Recently, there has been a renaissance in research about the institutional determinants of vertical boundary, with a focus on the roles of contracting institutions and financial institutions in determining firms' vertical boundary. Acemoglu, Johnson, and Mitton (2009) shows that the quality of contracting institutions does not have a direct impact on firm vertical boundary decision, but it has a negative, indirect impact through its interaction with the quality of financial institutions. Macchiavello (2010b) focuses on the role of financial institutions and shows that its impact on vertical integration depends on industry external finance reliance and industry heterogeneity in firm size distribution. Pascali (2009) finds that the quality of contracting institutions affects firm vertical boundary through asset specificity but not directly. Nonetheless, these studies utilize cross-country firm-level data sets, which may pose the challenge of controlling for the impacts of political system, culture and language, corporate tax policies, and national trade and 
investment policies across countries.

To corroborate our findings in this new literature on vertical integration (Acemoglu, Johnson, and Mitton, 2009; Macchiavello, 2010a, 2010b), we further investigate the role of financial institutions and its interaction with contracting institutions in determining vertical integration. It is found that financial institutions overall have no direct impact on vertical integration, but firms with greater reliance on external finance are less vertically integrated in regions with better financial institutions, consistent with the theoretical prediction of Macchiavello (2010b). Unlike Acemoglu, Johnson, and Mitton (2009), however, contracting institutions are found to have no interacting effect with financial institutions. Importantly, throughout these exercises, our main findings on the direct impact of contracting institutions on vertical integration remain robust.

Our study is also part of a large and growing literature on the importance of economic institutions for economic growth (e.g., Acemoglu, Johnson, and Robinson, 2001, 2002), incentives for investment (e.g., Besley, 1995; Johnson, McMillan, and Woodruff, 2002), and corporate decisions such as firm size (Laeven and Woodruff, 2007), FDI location choice (Du, Lu, and Tao, 2008) and family control of business (Lu and Tao, 2009).

The remainder of the paper is structured as follows. Section 2 introduces the data and variables for the empirical study, while Section 3 presents our main empirical results. The paper concludes with Section 4.

\section{Data and Variables}

The data used in this paper comes from the Survey of Chinese Enterprises (SCE), conducted by the World Bank in cooperation with the Enterprise Survey Organization of China in early 2003. ${ }^{5}$ For balanced representation, the SCE covered 18 cities from five geographic areas of China: Northeast - Benxi, Changchun, Dalian, and Harbin; Coastal region - Hangzhou, Jiangmen, Shenzhen, and Wenzhou; Central China - Changsha, Nanchang, Wuhan, and Zhengzhou; Southwest - Chongqing, Guiyang, Kunming, and Nanning; and Northwest - Lanzhou and Xi'an. There are altogether 1,566 firms in nine manufacturing industries: garment \& leather products, electronic equipment, electronic parts making, household electronics, automobile \& automobile parts, food processing, chemical products \& medicine, biotech products $\&$ Chinese medicine, and metallurgical products.

\footnotetext{
${ }^{5}$ It is a cross-sectional data set with most of the variables about firm operation and performance in 2002, though it also contains some financial information in the period 2000-2002.
} 
The dependent variable in our study is the degree of vertical integration in a firm. Following the literature (i.e., Adelman, 1955; Davies and Morris, 1995), we use the ratio of value added to sales to measure the degree of vertical integration. Specifically, it is constructed as the ratio of the difference between sales and purchased raw materials to sales and denoted by Value Added Ratio. Table 1 reports summary statistics of the data. Referring to Table 1, we can see that the mean value of Value Added Ratio is 0.487 $( \pm 0.247)$.

The ratio of value added to sales, however, has the drawback of being sensitive to the stage of the production process that a firm is specialized in (Holmes, 1999). Thus, for robustness check, we use an alternative measure of the degree of vertical integration. Specifically, it is constructed on the basis of the reply to the survey question of how large a proportion of inputs in terms of value is produced in-house by the firm itself, and denoted by SelfMade Input Percentage. However, as this measure is based on the subjective evaluations by managers, it is susceptible to substantial measurement errors. Indeed, referring to Table 1, we find that the standard deviation of Self-Made Input Percentage (0.401) is higher than that of Value Added Ratio. Since both measures of vertical integration have their own strengths and weaknesses, we employ both in our analysis to cross check the robustness of our findings.

Our key independent variable is the quality of contracting institutions. Here we follow Johnson, McMillan, and Woodruff (2002) and Cull and Xu (2005), and measure the quality of contracting institutions as the effectiveness of the legal system in dispute resolution. Specifically, in the survey, there is a question asking CEOs: "In your opinion, what is the likelihood that the legal system will uphold your contracts and property rights in business disputes?" The answer ranges from zero to 100 percent. The variable, Contracting Institutions, is constructed based on the responses to the question, with a higher value indicating better contracting institutions. Since most of business disputes are resolved in local courts in China, this variable reflects the perceived quality of contracting institutions in different cities. ${ }^{6}$

As shown in Table 1, Contracting Institutions has a mean value of 0.634 and a standard deviation of 0.389 , indicating significant variations across firms. Part of the variations comes from the inter-city variations in the quality of contracting institutions. For example, the average quality of contracting institutions is 0.498 in Xi'an, Shaanxi Province, while the corresponding number for Hangzhou, Zhejiang Province is 0.712. Indeed, when regressing

\footnotetext{
${ }^{6}$ According to the Civil Procedure Law of China (Articles 18-21), the civil lawsuit cases heard at first instance are in general taken care of by local courts at the city and county levels, although the plaintiff and the defendant have the right of appeal to a higher-level court.
} 
Contracting Institutions on industry and city dummies (along with a list of control variables related to enterprise and CEO characteristics), we find that city dummies are highly, statistically significant but not industry dummies (results available upon request). This is because that though China has a unified legal system, there are substantial variations in the interpretation and enforcement of laws and national ordinances enacted by the central government across China's various regions (see, for example, Clarke, 1996 and $\mathrm{Lu}$ and Tao, 2009 for more detailed discussions). ${ }^{7}$ Our measure, Contracting Institutions, is based on the enterprise's overall perception, thus capturing the de facto, rather than the de jure, quality of contracting institutions. However, this subjective measure may suffer from the endogeneity problem as well as the measurement error problem. To address these concerns, we conduct a series of robustness checks.

In a robustness check, we follow Cull and $\mathrm{Xu}$ (2005) in using an alternative measure of the quality of contracting institutions. Specifically, it is the percentage of business disputes encountered by a firm that are settled by courts as opposed to government arbitrations and private resolutions, and denoted by Court Litigation.

In the empirical analysis, we also controlled for other factors that might possibly affect vertical integration, including firm and CEO characteristics that are variously used in previous studies (Cull and Xu 2005; Li, Meng, Wang, and Zhou, 2008), as well as industry, city and industry-city dummies.

Variables related to firm characteristics include: Firm Size (measured by the logarithm of employment), Firm Age (measured by the logarithm of the number of years since establishment), Percentage of Private Ownership (measured by the percentage of ownership held by parties other than government agencies), Bank Loans (a dummy variable indicating whether the firm has any outstanding bank loans), and Degree of Computerization (measured by the percentage of workforce using computers regularly). ${ }^{8}$

\footnotetext{
${ }^{7}$ Indeed, a survey about "Doing Business in China" conducted by the World Bank in 2008 reveals substantial differences in the efficiency of courts to resolve business disputes across China's regions. For example, in coastal cities, it takes an average of 230 days to resolve an uncomplicated commercial dispute, whereas the corresponding number for Northeastern China is 363 days (World Bank, 2008).

${ }^{8} \mathrm{~A}$ larger firm and a firm with a longer history are likely to be more vertically integrated as the firm has a large production scale and sufficient expertise to incorporate a large number of production stages. A firm with a higher percentage of private ownership could be more vertically integrated because private enterprises, without government backup, may be disadvantaged in locating and making deals with intermediate goods suppliers. It has been argued that underdeveloped financial intermediaries promote vertical integration (Acemoglu, Johnson and Mitton, 2009). Under credit market imperfections, enterprises having obtained bank loans are typically those large and well-established firms which are
} 
Variables related to CEO characteristics include: his/her human capital - Education (years of schooling), Tenure (years as CEO), and Deputy CEO Previously (an indicator of whether the CEO had been the deputy CEO of the same enterprise before becoming CEO); and his/her political capital Government Cadre Previously (an indicator of whether the CEO had previously been a government official) and Party Membership (an indicator of whether the CEO was a member of the Chinese Communist Party). ${ }^{9}$

To deal with the potential endogeneity problems associated with the quality of contracting institutions, we apply the two-step Generalized Method of Moments (GMM) estimation method using two alternative instruments. One instrument is the average response by other firms located in the same city regarding the quality of contracting institutions (denoted by City Average of Contracting Institutions). The other instrument is a dummy variable indicating whether the respective city was administered by the Great Britain in the late Qing Dynasty (denoted by British Administration). We discuss the identification strategy using these instruments in Section 3.2.

As a further robustness check, we apply the heterogeneous response method of Rajan and Zingales (1998). Specifically, following Acemoglu, Johnson, and Mitton (2009), we examine whether the quality of contracting institutions has a greater impact on firm vertical boundary for firms that are more susceptible to supplier hold-up problems. To measure a firm's reliance on external suppliers, we first use the total number of suppliers (denoted by Suppliers) that a firm has as in Blanchard and Kremer (1997) and Rajan and Subramanian (2007). Second, same as in Acemoglu, Johnson, and Mitton (2009), we use the capital intensity, measured by the log of the ratio of fixed assets to sales and denoted by Capital Intensity. ${ }^{10}$ We expect that firms having a larger

more likely to be vertically integrated by self-producing intermediate goods. The degree of computerization may well reflect the degree of sophistication of the production process that the enterprises are involved in.

${ }^{9}$ We expect that CEOs with more education and managerial experience are more likely to run vertically integrated enterprises because their human capital enables them to coordinate various production stages smoothly. The impact of political capital on vertical integration may be ambiguous. On the one hand, entrepreneurs endowed with political capital may be more capable of dealing with suppliers in market transactions by smoothing the process of obtaining government approval or license etc. On the other hand, entrepreneurs with political capital may find it easy to expand production scale by winning government support so that vertical integration is more likely.

${ }^{10}$ We use the sample firms' capital intensity to measure the vulnerability of firms to holdup problems. As pointed out by Acemoglu, Johnson, and Mitton (2009), there seems no much variation in capital intensities of industries across countries. The capital intensities of sample firms should reflect the general industry characteristics. This also helps avoid the difficulty of matching the Chinese industry classification with the U.S. one if we are to use the US industry capital intensity as the benchmark. 
number of suppliers and a higher level of capital intensity are more likely to encounter severe contract disputes and need contracting institutions to help resolve disputes.

Finally, to investigate the role of financial institutions and its interaction with contracting institutions in determining vertical integration, we construct two additional variables. The first one is the measure of financial institutions, in which we use a dummy variable indicating whether the firm has any outstanding bank loans (denoted by Financial Institutions). ${ }^{11}$ The second one is the reliance on external finance, measured by 1 minus the ratio of internal funding for working capital following Rajan and Zingales (1998) and denoted by External Finance Reliance.

\section{Empirical Analysis}

\subsection{OLS Estimates}

We first conduct regression analysis with the following specification:

$$
y_{f i c}=\alpha+\beta \cdot R_{f i c}+\varepsilon_{f i c},
$$

where $y_{f i c}$ is the measure of vertical integration (i.e., Value Added Ratio and Self-Made Input Percentage) for firm $f$ located in city $c$ and industry $i ; R_{\text {fic }}$ is the quality of contracting institutions perceived by firm $f$ in city $c$ and industry $i$; and $\varepsilon_{f i c}$ is the error term. Robust standard error, clustered at the industry-city level, is used to deal with the heteroskedasticity problem.

Column 1 of Table 2 presents OLS estimate of specification (1). It is found that Contracting Institutions has a negative and statistically significant impact on Value Added Ratio. In terms of magnitude, a one-standard-deviation increase of Contracting Institutions is associated with a decrease of $0.389 \times$ $0.053=0.021$ in Value Added Ratio or $4.3 \%$ relative to the mean value of Value Added Ratio.

The above estimation results, however, could be biased due to the omission of relevant variables, i.e., $E\left(R_{f i c} \cdot \varepsilon_{f i c}\right) \neq 0$. To the extent that we can find a comprehensive set of control variables, $X_{\text {fic }}$, such that the residual error term, $\eta_{f i c}=\varepsilon_{f i c}-X_{f i c}^{\prime} \gamma$, is not correlated with $R_{f i c}$, then we can unbiasedly estimate the impact of contracting institutions on vertical integration.

\footnotetext{
${ }^{11}$ Note this is a firm-level measure, reflecting the de facto quality of financial institutions, rather than the de jure quality measured at the city-level. So long as firms determine their vertical boundaries in response to their de facto access to external finance, this firm-level measure produces a more precise estimate.
} 
We therefore stepwisely include, as controls, industry dummies, firm characteristics (firm size, firm age, percentage of private ownership, bank loans, and degree of computerization), CEO characteristics (human capital and political capital), city dummies, and industry-city dummies. Accordingly, the new estimation specification is:

$$
y_{f i c}=\alpha+\beta \cdot R_{f i c}+X_{f i c}^{\prime} \gamma+\eta_{f i c} .
$$

Columns 2-7 of Table 2 report the estimation results. It is clear that among all these specifications, Contracting Institutions always has a negative and statistically significant impact on Value Added Ratio, implying that firms perceiving stronger quality of contracting institutions are less vertically integrated. ${ }^{12}$

It should be pointed out that our results are in contrast to the findings by Acemoglu, Johnson, and Mitton (2009), in which the impacts of contracting institutions on vertical integration disappear once the industry dummies are included. Our strikingly different findings probably stem from several sources.

Firstly, the effects of industrial structure on firm vertical boundary could be rather different in their setting and ours. One way Acemoglu, Johnson, and Mitton (2009) explains their results is that those countries and regions with weaker contracting institutions could be more concentrated in industries that typically have a higher degree of vertical integration. In other words, countries and regions could choose industry structure or composition as a means of preventing the adverse effects of weak contracting institutions. In our setting, it is largely unlikely that a region's industry composition is shaped by contracting institutions. One prominent feature of the Chinese industrial structure is that it is fairly congruent across regions. In China,

\footnotetext{
${ }^{12}$ Note that in most of these regressions, we include the city dummy and hence the inference comes largely from the within-city rather than the cross-city variations in the quality of contracting institutions. In other words, our findings reflect the impact of heterogeneous institutional access rather than the quality of contracting institutions per se. Given that firms determine their vertical boundaries in response to the de facto quality of contracting institutions they face, our measure may produce more precise estimates. Nonetheless, we admit that the firm-level measure may suffer from the endogeneity problem and the measurement error problem. To address these concerns, we use various robustness checks in the following sections, including controlling various entrepreneurial and firm characteristics and employing the instrumental variable estimation. In addition, to mitigate the impacts of the variation in institutional access across entrepreneurs in a given city, we also conduct a reduced-form regression using city-average measure of contracting institutions, which presumably reflects primarily the cross-city variation in de facto contracting institutions. We obtain qualitatively similar results (available upon request), suggesting that our results still reflect to a large extent the effects of de facto contracting institutions on firm organization choice.
} 
considerations for self-sufficiency and self-containedness have long been the guiding principles for industrial structure arrangement. In the pre-reform cold-war period, the worries for wars breaking out in the east coastal areas and the wish to accelerate the industrialization and urbanization process of the country's western hinterland prompted the central government to relocate a substantial fraction of existing industrial capacity from the east coast to the western inland regions, and to favor inland areas in the allocation of new resources for industrial development. As a result, the leadership built a comprehensive set of industries in each province so that the national economy would not be severely disrupted even if the country temporarily lost some provinces, especially east coastal ones, during war times (called Xiao Er Quan in Chinese, i.e., each region is small but comprehensive). This trend has continued in the post-reform and post-cold-war era due to the local protectionism unleashed by the fiscal decentralization (Young, 2000; Bai, Du, Tao, and Tong, 2004; Lu and Tao, 2009). Local protectionism deters interregional resource allocation and regional industrial specialization. This lack of regional specialization prevents regions with weak contracting institutions from specializing in vertically integrated industries. This may explain why our results are still robust to the inclusion of industry dummies. Interestingly, the congruence in the Chinese interregional industrial structure actually provides an ideal setting to examine the impact of contracting institutions on firm organizational structure. It minimizes the impact of the choice of regional industrial specialization and industry characteristics on firms' decision on vertical boundary. It allows us to focus on how contracting institutions shapes firms' choice of organizational structure for any given industry.

Secondly, the difference in the measurement of contracting institutions could account for part of the differences in results. Acemoglu, Johnson, and Mitton (2009) use various indicators of procedural complexity to gauge the efficiency of contracting institutions across countries. Procedural complexity is measured by the number of procedures required to collect a commercial debt or bounced check. These measures are constructed on the basis of some objective measures reflecting de jure aspects of contracting institutions, which are convenient for international comparison. Nonetheless, as countries differ substantially in the efficiency of the administrative, judicial and commercial entities, the procedural complexity may not correspond perfectly with the actual efficiency of contracting institutions. In contrast, we use both the subjective assessment of contracting institution efficiency and the proportion of contract disputes resolved through court litigation. Given the national uniformity of legal procedure across regions in China, our measures could reflect to a large extent the de facto efficiency of contracting institutions in different regions. The different approaches to capturing contracting efficiency 
could be one additional reason for the differences in findings.

Finally, the differences in the measurement of vertical integration could contribute to the differences in the findings. For cross-country study, Acemoglu, Johnson, and Mitton (2009) use information from the input-output table to construct a firm-level vertical integration index, which largely reflects the opportunity for vertical integration. In contrast, we use value added ratio and the proportion of in-house produced inputs to measure vertical integration, albeit imperfect and subject to measurement error, are relatively more direct.

\subsection{GMM Estimates}

While we have a list of control variables $\left(X_{f i c}\right)$, it could still be possible that residual error term $\left(\eta_{f i c}\right)$, after controlling $X_{f i c}$, is correlated with the quality of contracting institutions $\left(R_{f i c}\right)$, i.e., $E\left(R_{f i c} \cdot \eta_{f i c}\right) \neq 0$, and hence the estimation results are biased due to this endogeneity issue. Specifically, the residual error term $\eta_{f i r}$ can be decomposed into two parts, $\omega_{f i c}$ and $\nu_{f i c}$, where $\omega_{f i c}$ is a firm/CEO characteristic observed by the firm but not by the econometrician, while $\nu_{f i c}$ is the error term observed by neither the firm nor the econometrician. ${ }^{13}$ Hence the correlation between $R_{f i c}$ and $\eta_{f i c}$ only comes from that between $R_{f i c}$ and $\omega_{f i c}$, i.e., $E\left(R_{f i c} \cdot \omega_{f i c}\right) \neq 0$.

To deal with this endogeneity issue, we adopt the instrumental variable estimation approach. Specifically, we decompose the quality of contracting institutions $\left(R_{f i c}\right)$ perceived by firm $f$ in city $c$ into two parts: the general quality of contracting institutions at city $c\left(R_{c}\right)$ and a firm-specific idiosyncratic component of contracting institutions $\left(r_{f i c}\right)$ that is independently and identically distributed, i.e., $R_{f i c}=R_{c}+r_{f i c}$.

Our identification strategy depends on whether the general quality of contracting institutions at city $c\left(R_{c}\right)$ is orthogonal to the unobserved firm characteristics $\left(\omega_{f i c}\right)$, i.e.,

$$
E\left(R_{c} \cdot \omega_{f i c}\right)=0 .
$$

Since the unobserved firm/CEO characteristic, $\omega_{f i c}$, is the residue after controlling for a host of variables, particularly CEO human capital and political capital, it is unlikely that this unobserved firm/CEO characteristic would be correlated with the general quality of contracting institutions in the city.

\footnotetext{
${ }^{13}$ Note that all variables at the industry, city and industry-city level have been controlled by the inclusion of industry and city dummies (Column 6 of Table 2) and industry-city dummies (Column 7 of Table 2).
} 
Given that assumption (3) is satisfied, the general quality of contracting institutions in the city, $R_{c}$, is a valid instrument for our key explanatory variable, $R_{f i c}$. Specifically, we use the city-level average perception of contracting institutions among other firms in the same city as the proxy for $R_{c}$.

In addition, to check robustness to assumption (3), we also use an alternative instrumental variable, viz., the indicator of whether a city was administered by the Great Britain in the late Qing Dynasty. This is motivated by the recent literature on economic institutions (La Porta, Lopez-de-Silanes, Shleifer, and Vishny, 1997, 1998).

\subsubsection{Instrumental Variable I: Average Assessment of Contracting Institutions by Other Firms in the Same City}

To proxy for the general quality of contracting institutions in city $c\left(R_{c}\right)$, we use the average assessment of the quality of contracting institutions by other surveyed firms in the same city. Specifically, the first instrumental variable, City Average of Contracting Institutions $\left(I V 1_{f c}\right)$, for firm $f$ located in city $c$ is:

$$
I V 1_{f c}=\frac{1}{n_{c}-1} \sum_{\substack{j \in \Omega_{c} \\ j \neq f}} R_{j c}=R_{c}+\frac{1}{n_{c}-1} \sum_{\substack{j \in \Omega_{c} \\ j \neq f}} r_{j c}
$$

where $\Omega_{c}$ is the set of firms located in city $c ; n_{c}$ is the number of firms located in city $c$; and $R_{j c}$ is the quality of contracting institutions perceived by another firm $j$ in city $c$.

The validity of the instrumental variable estimation hinges upon two conditions, the relevance condition and the exclusion restriction. The relevance condition means the instrumental variable is correlated with the endogenous variable, i.e., $E\left(I V 1_{f c} \cdot R_{f i c}\right) \neq 0$, which can be confirmed by the regression analysis and several econometric tests. And given the assumption (3) and i.i.d. of $r_{f c}$, we show in the Appendix A.1 that our instrumental variable I satisfies the exclusion restriction, i.e.,

$$
E\left(I V 1_{f c} \cdot \eta_{f i c}\right)=0 .
$$

Regression results using this instrumental variable $\left(I V 1_{f c}\right)$ are reported in Column 1 of Table $3 .{ }^{14}$ The relevance condition of the instrumental variable is confirmed by the highly significant correlation between the instrumental variable $\left(I V 1_{f c}\right)$ and the quality of contracting institutions perceived by the

\footnotetext{
${ }^{14}$ As the instrumental variable is at the city-level which preclude the use of city dummies, we include Logarithm of GDP per capita and Logarithm of Population to control for the city-level general environments.
} 
firm $\left(R_{f i c}\right)$, and the result of the Anderson canonical correlation LR statistic (Panel B of Table 3). Meanwhile, the concern for weak instrument is ruled out by the large Shea partial R-squared and the result of the Cragg-Donald F-statistic (Panel B of Table 3). ${ }^{15}$

Panel A of Table 3 shows that Contracting Institutions, instrumented by the average assessment of the quality of contracting institutions by other surveyed firms in the same city, has a negative and statistically significant impact on Value Added Ratio. In Panel C, we report the corresponding OLS estimate for Contracting Institutions, and the Dubin-Wu-Hausman test. The insignificance of the Dubin-Wu-Hausman test indicates that the OLS estimate is statistically not different from the two-step GMM estimate.

Note that the magnitude of the GMM estimate coefficient of Contracting Institutions is about 4 times as large as the OLS estimate one. Apparently, some omitted variables that are correlated with our outcome variable and the key explanatory variable in the same directions bias the impact of contracting institutions downward in magnitude. For example, a more capable entrepreneur may on one hand have better connections that help her/him secure better de facto contract enforcement, and on the other hand be capable of managing more vertically-integrated businesses. Hence, the lack of control for entrepreneurial capability may again lead to an underestimation of the impact of contracting institutions. Another possibility is the existence of measurement errors associated with the perceived quality of contracting institutions, which biases the OLS estimates downward in magnitude towards zero.

In terms of control variables, they mostly produce statistically insignificant estimates. Nonetheless, there are two exceptions. First, the degree of computerization exhibits positive and significant estimated coefficients. This suggests that firms engaged in more technologically advanced production have higher value added ratio. The fact that we obtain significant estimated coefficients for Contracting Institutions after including the degree of computerization demonstrates that our results are unlikely driven by the concentration of firms with sophisticated technology in regions with weaker contracting institutions. Second, the Party membership turns out positive and significant estimated coefficients. This shows that political capital could be leveraged by entrepreneurs to different stages of the production process so as to facilitate vertical integration.

Further checks on the identification strategy. The identification strategy of the above two-step GMM estimation lies in that the instrumental

\footnotetext{
${ }^{15}$ The Cragg-Donald F-statistic values for our regressions are significantly above the value of 10, which is considered as the critical value by Staiger and Stock (1997).
} 
variable is orthogonal to the error term, i.e., $E\left(I V 1_{c} \cdot \eta_{f i c}\right)=0$. A potential concern is that in China courts are strongly influenced by the local government officials. This is because the local governments provide finance to the courts and they also make the appointment of court judges. To address this concern, we add a variable, Ability of Government Officials (measured by the city-average perceived percentage of competent officials among the government officials that the firm regularly interacts with), as an additional control, and find that our results remain robust (Column 2 of Table 3 ).

To further check on this identification strategy, we conduct a test following Acemoglu, Johnson, and Robinson (2002). Specifically, we re-write the orthogonal condition (equation (5)) in the form of mean-independence, i.e.,

$$
E\left(\eta_{f i c} \mid I V 1_{f c}, R_{f i c}, X_{f i c}\right)=E\left(\eta_{f i c} \mid R_{f i c}, X_{f i c}\right) .
$$

In other words, after the endogenous variable $\left(R_{f i c}\right)$ as well as $X_{f i c}$ are controlled for, the instrumental variable $\left(I V 1_{f c}\right)$ does not have any partial impact on the outcome variable. As shown in Column 3 of Table 3 , in the reduced-form regression of the outcome variable on the instrumental variable (along with $X_{f i c}$ but not $R_{f i c}$ ), the instrumental variable has a negative and statistically significant estimated coefficient, which is consistent with our earlier findings. ${ }^{16}$ However, in Column 4 of Table 3, when the endogenous variable $\left(R_{f i c}\right)$ is included as an additional control, the instrumental variable no longer has any statistical significance, which implies the satisfaction of equation (6) and validity of the instrumental variable estimation.

\subsubsection{Instrumental Variable II: British Administration in Late Qing Dynasty}

The second instrumental variable we use is a dummy variable (British Administration) indicating whether a city was administered by the Great Britain in the late Qing Dynasty of Imperial China, as in Lu and Tao (2009). Motivated by the recent literature on legal origins (La Porta, Lopez-de-Silanes, Shleifer, and Vishny, 1997 and 1998), Lu and Tao (2009) exploit a unique historical period in the late Qing dynasty of Imperial China when territories were administered by different foreign powers with different legal origins, and use British Administration as the instrumental variable for the quality of contracting institutions (for details on the rationale of this instrumental

\footnotetext{
${ }^{16}$ As pointed out by Angrist and Krueger (2001), Chernozhukov and Hansen (2008) and Angrist and Pischke (2009), if the instrumental variable does not have any statistical significance in this reduced-form regression, then it implies that the endogenous variable may also not have any statistically significant impact on the outcome variable.
} 
variable, see Appendix A.2 and Lu and Tao (2009)). ${ }^{17}$

Regression results using this instrumental variable are summarized in Column 1 of Table 4 . With regard to the relevance condition for an effective instrument, British Administration is highly and positively correlated with the quality of contracting institutions $\left(R_{f i c}\right)$. The relevance condition is further confirmed by the Anderson canonical correlation LR statistic. Meanwhile, the concern for weak instrument is ruled out by the large Shea partial Rsquared and the result of the Cragg-Donald F-statistic (Panel B of Table 4). With respect to the central issue of IV regression results, Panel A of Table 4 shows that Contracting Institutions, instrumented by British Administration, has a negative and statistically significant impact on Value Added Ratio.

Further checks on the identification strategy. A potential concern with this instrumental variable estimation is that legal origins are shown to have impacts on many aspects of the economy other than the quality of contracting institutions. For example, it has been shown the common law system is associated with more developed financial institutions (La Porta, Lopez-de-Silanes, Shleifer, and Vishny, 1997, 1998; Djankov, McLiesh, and Shleifer, 2007), less regulation of entry and less corruption (Djankov, La Porta, Lopez-de-Silanes, and Shleifer, 2002), lower government ownership of banks and lower interest rates (La Porta, Lopez-de-Silanes, and Shleifer, 2002), higher quality of government services (La Porta, Lopez-de-Silanes, Shleifer, and Vishny, 1999), and lower levels of labor regulation (Botero, Djankov, La Porta, Lopez-de-Silanes, and Shleifer, 2004). These other aspects of the economy could potentially affect the firm's willingness to vertically integrate. For example, more stringent government regulation of entry could result in the prevalence of large-scale firms that are more likely to be vertically integrated. If these other aspects of the economy cast significant impacts on a firm's willingness to vertically integrate, it means that legal origins may affect our outcome variable through channels other than the quality of contracting institutions, causing the violation of the exclusion restriction of the instrumental variable estimation.

To address the above concern, we construct additional control variables related to each of these possible channels, and stepwisely include them in the regression as robustness checks. Specifically, we include Ability of Government Officials (measured by the city-average perceived percentage of competent officials among the government officials that the firm regularly interacts with) as a proxy for the quality of government services, Regulation of Labor (measured by the percentage of firms having labor redundancy), Interest

\footnotetext{
${ }^{17}$ Similarly, Berkowtiz and Clay $(2005,2006)$ also look at the relation between the legal origin and the quality of contracting institutions within the United States.
} 
Rate (measured by the city-average annual interest rate), Financial Development (measured by the percentage of firms having outstanding bank loans), and Regulation of Entry (measured by the city average ratio of the unofficial payment to the total costs of obtaining a registration or license).

As shown in Columns 2-6 of Table 4, our main result concerning the impact of the quality of contracting institutions on vertical integration remains robust to these controls.

\subsection{Heterogeneous Response Estimation}

As a further robustness check, we apply the heterogeneous response method of Rajan and Zingales (1998). The identification of this method hinges upon the theoretical mechanisms through which contracting institutions may affect vertical integration.

According to Acemoglu, Johnson, and Mitton (2009)'s theory, the quality of contracting institutions has a greater impact on firm vertical boundary for firms that are more susceptible to supplier hold-up problems. It is expected that firms dealing with many suppliers or having high capital intensity are more reliant on external suppliers and are thus more likely to encounter supplier holdup problems. Specifically, we estimate the following equation:

$$
y_{f i c}=\alpha+\beta \cdot R_{f i c}+\delta \cdot R_{f i c} \times S_{f i c}+\eta \cdot S_{f i c}+X_{f i c}^{\prime} \gamma+\eta_{f i c},
$$

where $S_{f i c}$ is a measure of firms' reliance on external suppliers, which is either the total number of suppliers as used by Blanchard and Kremer (1997) and Rajan and Subramanian (2007) or the capital intensity, i.e. the logarithm of the ratio of fixed assets to total sales, as in Acemoglu, Johnson, and Mitton (2009).

Regression results are reported in Table 5, in which the total number of suppliers is used in Column 1 whereas the capital intensity is used in Column 2. Clearly, in both cases, it is found that indeed the impact of contracting institutions on vertical integration is greater for firms that rely more heavily on external suppliers, consistent with the theoretical predictions and empirical findings of Acemoglu, Johnson, and Mitton (2009). Moreover, the direct effect of contracting institutions on vertical integration remains robust in these exercises.

\subsection{Robustness Checks}

We conduct six other sets of robustness checks of the impact of the quality of contracting institutions on vertical integration. First, we use an alternative 
measure of vertical integration, i.e., the percentage of inputs in terms of value that is produced in-house by the firm itself (denoted by Self-Made Input Percentage). The OLS and the two-step GMM (using the average assessment of the quality of contracting institutions by other surveyed firms in the same city as the instrument) estimates are reported in Columns 1-2 of Table 6 , respectively. It is found that the quality of contracting institutions has a negative impact on vertical integration in both regressions, though only the two-step GMM estimate is statistically significant. Meanwhile, the Dubin-Wu-Hausman test is statistically significant, implying that the OLS estimate may be biased due to the endogeneity issue and/or the measurement error problem.

Second, we use an alternative measure of the quality of contacting institutions, i.e., the percentage of business disputes encountered by a firm that are settled by courts (denoted by Court Litigation). The OLS and the two-step GMM (using the average assessment of the quality of contracting institutions by other surveyed firms in the same city as the instrument) estimates are reported in Columns 3-4 of Table 6, respectively. It is found that the quality of contracting institutions still has a negative impact on vertical integration in both regressions, though only the OLS estimate is statistically significant. Meanwhile, the Dubin-Wu-Hausman test is statistically insignificant, indicating that the two-step GMM estimate is not statistically different from the OLS estimate.

Third, for firms with many businesses, the degree of vertical integration could vary from one business to another. Thus our measure of vertical integration may reflect the average degree of vertical integration across various businesses, which may bias our estimations of the impacts of the quality of contracting institutions on vertical integration. To alleviate this concern, we focus on the sub-sample of firms with focused business (defined as firms whose main business contributes at least $90 \%$ to their total sales). The results shown in Columns 1-2 of Table 7 suggest that our main findings remain robust to this sub-sample.

Fourth, China's state-owned firms were the main players under the central planning system. Even during China's economic transition, state-owned firms are favored by the government, thus enjoying better de facto treatment from contracting institutions. At the same time, influenced by the principle of self-sufficiency under the central planning system, state-owned firms have continued to be vertically integrated. To make sure that our results are not biased due to the inclusion of these state-owned firms, we focus on the subsample of private firms (defined as firms with private ownership accounting for at least $90 \%$ shares). As shown in Columns 3-4 of Table 7, our main findings remain robust to this sub-sample. 
Lastly, one may be concerned that our results could be driven by larger firms that are more likely to vertically integrate and thus less prone to the risks of poor contracting institutions. To deal with this concern, we focus on the subsample of smaller firms (excluding the top $10 \%$ firms in terms of employment). ${ }^{18}$ As shown in Columns 5-6 of Table 7, the impacts of the quality of contracting institutions on vertical integration remain negative and significant.

\subsection{The Role of Financial Institutions}

The recent literature on the relationship between institutional quality and vertical integration has paid much attention to the importance of financial institutions. Acemoglu, Johnson, Mitton (2009) find no direct effects of contracting institutions and financial development on the extent of vertical integration, but detect greater vertical integration in countries that have both weaker contracting institutions and better financial development. Macchiavello (2010b) shows that the impact of financial institutions on vertical integration is complicated, hinging upon the firm size distribution within an industry. Specifically, it argues that in an industry where small firms are more prevalent, financial institutions reduce the degree of vertical integration. This is expected to hold in our data set as the firms in our data are relatively small. Following Macchiavello (2010a), we thus estimate the following equation:

$$
y_{f i c}=\alpha+\beta \cdot F_{f i c}+\delta \cdot F_{f i c} \times E_{f i c}+\eta \cdot E_{f i c}+X_{f i c}^{\prime} \gamma+\eta_{f i c},
$$

where $F_{f i c}$ measures the quality of financial institutions; and $E_{f i c}$ is a measure of external finance reliance (à la Rajan and Zingales, 1998).

Regression results are reported in Table 8 . In Column 1, we only include the single term of the quality of financial institutions, and find that it does not have any direct effect on vertical integration, in line with the complicated relations between financial institutions and vertical integration elucidated by Macchiavello (2010b). In Column 2, we interact financial institutions with the external finance reliance, and find that firms with greater reliance on external finance are less vertically integrated when facing better financial institutions. ${ }^{19}$ Given the small firm size nature of our sample, this finding

\footnotetext{
${ }^{18}$ Results are similar when the top $25 \%$ or top $50 \%$ firms are excluded from the sample.

${ }^{19}$ Estimation using external finance reliance data of U.S. industries (adopted from Rajan and Zingales, 1998) shows that the interaction term is also negative, albeit statistically insignificant. Presumably this is due to the imperfect matching between the U.S. industry classification and the industry classification used in our data.
} 
is consistent with the theoretical predictions and the empirical findings of Macchiavello (2010b).

In Columns 3-4, we add the quality of contracting institutions and its interaction term with external finance reliance. It is found that the quality of contracting institutions remains to have negative and statistically significant impact on vertical integration, reinforcing our main results in earlier sections. Meanwhile, the interacting role of financial institutions with external finance reliance remains robust to the control of contracting institutions, implying the importance of financial institutions for firm vertical boundary decision.

Lastly, in Column 5, we further include the interaction term between financial institutions and contracting institutions. It is found that unlike Acemoglu, Johnson, and Mitton (2009), contracting institutions do not have differential impact on vertical integration through financial institutions. Understandably, as argued by Macchiavello (2010b), the impact of financial institutions on vertical integration is to be complicated, and it mainly functions through interactions with firm external finance reliance and firm size distribution within an industry.

\section{Conclusion}

The make-or-buy decision is an important one for business strategy, firm performance, and ultimately economic growth. In explaining the determinants of vertical integration, the existing literature mainly focuses on contractual incompleteness and asset specificity by taking for granted that there are sound contracting institutions. Given that the quality of contracting institutions is imperfect even in some developed economies and far more problematic in developing countries, the investigation of the impacts of the quality of contracting institutions on vertical integration is highly needed.

In this paper, using a data set of manufacturing firms in China, we investigate how the variations in the quality of contracting institutions across China's cities affect the degree of vertical integration. We find that the quality of contracting institutions has a negative and significant impact on vertical integration. The results are robust to the inclusion of a comprehensive list of controls variables, to the use of instrumental variable estimation and the heterogeneous response estimation, to alternative measures of key variables, to the use of various sub-samples, and to the control for the quality of financial institutions. Our findings highlight the importance of contracting institutions on firm organizational choice, and offer potential policy recommendations as the organization choice subsequently affects firm performance and economic growth. 


\section{References}

[1] Acemoglu, Daron, Simon Johnson, and Todd Mitton. 2009. "Determinants of Vertical Integration: Financial Development and Contracting Costs", Journal of Finance 63, 1251-1290.

[2] Acemoglu, Daron, Simon Johnson, and James A. Robinson. 2002. "Reversal of Fortune: Geography and Institutions in the Making of the Modern World Income Distribution", Quarterly Journal of Economics 117, 1231-1294.

[3] Adelman, M. A. 1955. "Concept and Statistical Measurement of Vertical Integration", in George J. Stigler, ed., Business Concentration and Price Policy, Princeton, NJ: Princeton University Press.

[4] Angrist, Joshua and Alan Krueger. 2001. "Instrumental Variables and the Search for Identification: From Supply and Demand to Natural Experiments", Journal of Economic Perspectives 15, 69-85.

[5] Angrist, Joshua and Jörn-Steffen Pischke. 2009. Mostly Harmless Econometrics, Princeton, NJ: Princeton University Press.

[6] Bai, Chong-en, Yingjuan Du, Zhigang Tao, and Sarah Tong. 2004. "Protectionism and Regional Specialization: Evidence from China's Industries", Journal of International Economics 63, 397-417.

[7] Berkowitz, Daniel and Karen Clay. 2005. "American Civil Law Origins: Implications for State Constitutions and State Courts", American Law and Economics Review 7, 62-84.

[8] Berkowitz, Daniel and Karen Clay. 2006. "The Effect of Judicial Independence on Courts: Evidence from the American States", Journal of Legal Studies 35, 399-400.

[9] Botero, Juan C., Simeon Djankov, Rafael La Porta, Florencio Lopez-deSilanes, and Andrei Shleifer. 2004. "The Regulation of Labor", Quarterly Journal of Economics 119, 1339-1382.

[10] Chernozhukov, Victor and Christian Hansen. 2008. "The Reduced Form: A Simple Approach to Inference with Weak Instruments", Economcs Letters 100, 68-71.

[11] Clarke, Donald. 1996. "Power and Politics in the Chinese Court System: the Enforcement of Civil Judgments", Columbia Journal of Asian Law 10, 1-92. 
[12] Coase, Ronald. 1937. "The Nature of the Firm", Economica 4, 386-405.

[13] Cull, Robert, and Lixin Colin Xu. 2005. "Institutions, Ownership, and Finance: the Determinant of Profit Reinvestment among Chinese Firms", Journal of Financial Economics 77, 117-146.

[14] Davies, S. and C. Morris. 1995. "A New Index of Vertical Integration: Some Estimates for UK Manufacturing", International Journal of Industrial Organization 13, 151-177.

[15] Djankov, Simeon, Rafael La Porta, Florencio Lopez-de-Silanes, and Andrei Shleifer. 2002. "The Regulation of Entry", Quarterly Journal of Economics 117, 1-37.

[16] Djankov, Simeon, Caralee McLiesh, and Andrei Shleifer. 2007. "Private Credit in 129 Countries", Journal of Financial Economics 84, 299-329.

[17] Du, Julan, Yi Lu, and Zhigang Tao. 2008. "Economic Institutions and FDI Location Choice: Evidence from US Manufacturing Firms in China", Journal of Comparative Economics 36, 412-429.

[18] Fan, Joseph, Jin Huang, Randall Morck, and Bernard Y. Yeung. 2007. "Institutional Determinants of Vertical Integration: Evidence from China", working paper.

[19] Grossman, Sanford J., and Oliver Hart. 1986. "The Costs and Benefits of Ownership: A Theory of Vertical and Lateral Integration", Journal of Political Economy 94, 691-719.

[20] Hart, Oliver, and John Moore. 1990. "Property rights and the Nature of the Firm", Journal of Political Economy 986, 1119-1158.

[21] Holmes, Thomas J. 1999. "Localization of Industry and Vertical Disintegration", Review of Economics and Statistics 81, 314-325.

[22] Johnson, Simon, John McMillan, and Christopher Woodruff. 2002. "Property Rights and Finance", American Economic Review 22, 13351356.

[23] Klein, Benjamin, Robert G. Crawford, and Armen A. Alchian. 1978. "Vertical Integration, Appropriable Rents, and the Competitive Contracting Process", Journal of Law and Economics 21, 297-326.

[24] La Porta, Rafael, Florencio Lopez-de-Silanes, and Andrei Shleifer. 2002. "Government Ownership of Banks", Journal of Finance 57, 265-301. 
[25] La Porta, Rafael, Florencio Lopez-de-Silanes, Andrei Shleifer and Robert Vishny. 1997. "Legal Determinants of External Finance", Journal of Finance 52, 1131-1150.

[26] La Porta, Rafael, Florencio Lopez-de-Silanes, Andrei Shleifer and Robert Vishny. 1998. "Law and Finance", Journal of Political Economy 106, 1113-1155.

[27] La Porta, Rafael, Florencio Lopez-de-Silanes, Andrei Shleifer, and Robert Vishny. 1999. "The Quality of Government", Journal of Law, Economics and Organization 15, 222-279.

[28] Lafontaine Francine, and Margaret Slade. 2007. "Vertical Integration and Firm Boundaries: the Evidence", Journal of Economic Literature $45,629-685$.

[29] Li, Hongbin, Lingsheng Meng, Qian Wang, and Li-An Zhou, 2008. "Political Connections, Financing and Firm Performance: Evidence from Chinese Private Firms", Journal of Development Economics 87, 283299.

[30] Lin, Ping, Chen Lin, and Frank Song. 2010. "Property Rights Protection and Corporate R\&D: Evidence from China", Journal of Development Economics, Forthcoming.

[31] Lu, Jiangyong and Zhigang Tao. 2009. "Trends and Determinants of China's Industrial Agglomeration", Journal of Urban Economics 65, 167-180.

[32] Lu, Yi and Zhigang Tao. 2009. "Contract Enforcement and Family Control of Business: Evidence from China", Journal of Comparative Economic 37, 597-609.

[33] Staiger, Douglas, and James Stock. 1997. "Instrumental Variables Regression with Weak Instruments", Econometrica 65, 557-586.

[34] Williamson, Oliver E. 1971. "The Vertical Integration of Production: Market Failure Consideration", Americal Economic Review 61, 112-123.

[35] Williamson, Oliver E. 1985. The Economic Institutions of Capitalism. New York: Free Press.

[36] World Bank. 2008. Doing Business in China 2008, Beijing, China: Social Science Academic Press. 
[37] Young, Alwyn. 2000. "The Razor's Edge: Distortions and Incremental Reform in the People's Republic of China", Quarterly Journal of Economics 115, 1091-1135. 


\section{Appendix A.1}

\section{Proof of Equation (5)}

$$
\begin{aligned}
E\left(I V 1_{f c} \cdot \eta_{f i c}\right) & =E\left(\left[R_{c}+\frac{1}{n_{c}-1} \sum_{\substack{j \in \Omega_{c} \\
j \neq f}} r_{j c}\right] \cdot \eta_{f i c}\right) \\
& =E\left(\left(R_{c}+\frac{1}{n_{c}-1} \sum_{\substack{j \in \Omega_{c} \\
j \neq f}} r_{j c}\right) \cdot \omega_{f i c}\right) \\
& =E\left(R_{c} \cdot \omega_{f i c}\right)+E\left(\frac{1}{n_{c}-1} \sum_{\substack{j \in \Omega_{c} \\
j \neq f}} r_{j c} \cdot \omega_{f i c}\right)=0,
\end{aligned}
$$

where the last equality comes from assumption (3) and i.i.d. of $r_{f c}$.

\section{Appendix A.2}

During the late Qing Dynasty (1840-1911), China was defeated in a series of wars against foreign powers, including two Opium Wars with the Great Britain, the Sino-Japanese War of 1894-95, and the Boxer Rebellion. In the wake of military defeats, the Qing government was forced to sign unequal treaties including territorial concessions. The wave of territorial partitioning climaxed at the end of the nineteenth century. The Great Britain administered nine regions (Guizhou, Sichuan, Hubei, Hunan, Jiangxi, Anhui, Jiangsu, Henan, and Zhejiang provinces); France controlled Yunnan, Hainan, Guangxi, and the majority of Guangdong province; Germany administered Shandong province; Japan governed Fujian province; and Russia controlled Xinjiang, Mongolia, and the three north-eastern provinces (Qian, 1948). Shanghai and Tianjin, the two leading commercial centers of China at the time, were divided into various foreign concessions.

Three main reasons account for the geographical pattern of territorial partitioning by the foreign powers. First, the geographic proximity between the foreign powers and China's regions is a primary force in shaping the pattern of territorial concessions (Dougherty and Pfaltzgraff, 2000). For example, Russia, located to the north of China, occupied most of China's northern regions such as Xinjiang, Mongolia, and the three northeastern provinces. France, 
stepping from its colony of Vietnam that lies to the southwest of China, extended its colonial power to the four southwestern provinces in China, i.e., Yunnan, Hainan, Guangxi, and the majority of Guangdong province (Yang, 2006). Japan, defeated by Russia in its aggression in the Northeast China, chose to occupy China's regions such as Taiwan and Fujian that are close to its southern territories. The second reason for the territorial partitioning is for the control of certain products that the foreign powers needed at the time. For example, the Great Britain, which was a big importer of tea and silk from China, chose to occupy those regions in China that produced these two products (Sa and Pan, 1996). Finally, the territorial occupation of Germany, a power which was late in joining the occupation of China, was a result of bargaining and negotiation with other foreign powers (China History Society, 1959). Hence, the geographical pattern of territorial concessions had nothing to do with the initial institutional strength and the industrial development capacity of different regions. It can be regarded as an exogenous process. On the contrary, the quasi-colonial experience contributes to the variations in institutional strength across regions in China.

Within their respective domains of control, the foreign powers effectively established their sovereign authorities (McAleavy, 1967). Typically, the foreign powers imposed their own civil and military administration, including legal system, police, and education (Dong, Zhang, and Jiao 2000). In particular, lawsuits taking place in those domains controlled by foreign powers were adjudicated using the legal systems of respective reigning foreign powers (e.g., Yang and Ye, 1993; Tan, 1996). The foreign powers imposed their own civil and military administration by force and hence, the administrative systems could be considered as being exogenous to the local communities.

Contemporary China is a united sovereign nation with a unified legal system. However, there are substantial variations in the interpretation and enforcement of laws and national ordinances enacted by the central government across China's various regions (e.g., Clarke, 1996). Due to the substantial variations in endowments, technologies and economic development across regions in China, local governments often issue various rules and regulations regarding laws and national ordinances so as to make them more adapted to the local circumstances (e.g., Chen, 2004; Clarke, Murrell, and Whiting, 2008). Furthermore, the enforcement of rules and regulations hinges upon the cooperation of local people as well as local authorities (e.g., Fan, 1985; Lieberthal and Oksenberg, 1988; Zhao, 1989; Li, Zhang, and Wang, 1990; Clarke, 1991), which again varies substantially across China's regions due to the differences in culture, beliefs, and ideologies (e.g., Tai, 1957; Cheng, Liu, and Cheng, 1982; Yearbook of People's Court, 1990; Clarke, 1996).

The imposition of the legal systems by the foreign powers in various parts 
of China in the late Qing Dynasty is expected to influence not only the legal rules and the legal institutions (including judicial independence and legal procedures) at that time, but also the fundamental legal culture, i.e., human capital and beliefs of the key participants in the legal systems (Zweigert and Kotz, 1998; La Porta, Lopez-de-Silanes, and Shleifer, 2008). Indeed, the foreign powers in China were actively engaged in transplanting and cultivating their beliefs and ideologies to the local people by setting up and operating schools and colleges. Speaking at the Second Protestantism Propagators Congress held in Shanghai in China in 1890, F.L. Hawks Pott, President of Saint John's University, declared that "in our school, we trained China's future teachers and propagators, making them the leaders and comperes in the future and casting the greatest influences on the future China" (Yang and Ye 1993). The legal institutions, human capital and beliefs that were transplanted and cultivated by different foreign powers are expected to persist over time (Zweigert and Kotz, 1998; Balas, La Porta, Lopez-de-Silanes, and Shleifer, 2009). Indeed, there is a growing body of literature on the persistence of culture, beliefs, and ideologies over time (e.g., Bisin and Verdier, 2000; Dohmen, Falk, Huffman, and Sunde, 2006; Tabellini, 2007a, 2007b, 2009). The persistent legal culture shapes the beliefs and behavioral patterns of the current generation. The regional variation in legal culture could determine the variation in the de facto law enforcement across regions. The leeway that each region enjoys in interpreting national laws and ordinances and adapting them to local circumstances serves as a medium through which the variation in the legal culture could be revealed in the current legal practices, including the effectiveness of contract enforcement.

The foreign powers belong to different legal families. According to La Porta, Lopez-de-Silanes, Shleifer, and Vishny $(1997,1998)$, legal origin affects the effectiveness of contract enforcement. Specifically, contract enforcement is more effective under the common law system used by the Great Britain than under the civil law system used by France, Germany, Japan, and Russia (e.g., Acemoglu and Johnson, 2005). Accordingly, we expect that the local legal and business culture in the British-administered regions in China may be more conducive to contract enforcement than those in regions under the administration of other foreign powers. Hence, we take whether a city of China was administered by the Great Britain during the late Qing Dynasty as a reasonable instrument for the effectiveness of contract enforcement in $2002 .^{20}$

\footnotetext{
${ }^{20}$ Nine out of the eighteen cities (Changsha, Chongqing, Guiyang, Hangzhou, Nanchang, Shenzhen, Wenzhou, Wuhan, and Zhengzhou) in our sample were administered by the Great Britain, and the rest of the sample was occupied by France or Russia.
} 


\section{References}

[1] Acemoglu, Daron and Simon Johnson. 2005. "Unbundling Institutions", Journal of Political Economy 113, 949-995.

[2] Balas, Aron, Rafael La Porta, Florencio Lopez-de-Silanes, and Andrei Shleifer. 2009. "The Divergence of Legal Procedures", American Economic Journal: Economic Policy, forthcoming.

[3] Bisin, Alberto and Thierry Verdier (2000) "Beyond the Melting Pot: Cultural Transmission, Marriage, and the Evolution of Ethnic and Religious Traits", Quarterly Journal of Economics 115, 955-988.

[4] Chen, Albert. 2004. An Introduction to the Legal System of the People's Republic of China (3rd ed.), Hong Kong: Butterworths.

[5] Cheng, Cheng, Jiaxing Liu, and Yanling Cheng. 1982. "On some Problems in Civil Execution in China", Studies in Law (Faxue Yanjiu in Chinese) 1.

[6] China History Society. 1959. Selected Works of Shandong Province's Modern History (Shandong Jindai Shi Ziliao Xuanji in Chinese), Shandong, China: Shandong People's Publishing House.

[7] Clarke, Donald. 1991. "Dispute Resolution in China", Journal of Chinese Law 5, 244-296.

[8] Clarke, Donald. 1996. "Power and Politics in the Chinese Court System: the Enforcement of Civil Judgments", Columbia Journal of Asian Law 10, $1-92$.

[9] Clarke, Donald, Peter Murrell, and Susan Whiting. 2008. "The Role of Law in China's Economic Development", in Thomas Rawski and Loren Brandt ed., China's Great Economic Transformation, Cambridge University Press.

[10] Dohmen, Thomas, Armin Falk, David Huffman, and Uwe Sunde. 2006. "The Intergenerational Transmission of Risk and Trust Attitudes", IZA DP 2380.

[11] Dougherty, James E. and Robert L. Pfaltzgraff. 2000. Contending Theories of International Relations: A Comprehensive Survey, New York: Longman. 
[12] Dong, Shouyi, Lizhen Zhang, and Runmin Jiao. 2000. Lectures on Modern History of China Volume I, Beijing, China: Chinese Social Science Press.

[13] Fan, Chengzhi. 1985. "The Position of the People's Courts in the Structure of the State", Jurisprudence Magazine (Faxue Zazhi in Chinese) 4.

[14] La Porta, Rafael, Florencio Lopez-de-Silanes, and Andrei Shleifer. 2008. "The Economics Consequences of Legal Origins", Journal of Economic Literature 46, 285-332.

[15] La Porta, Raael, Florencio Lopez-de-Silanes, Andrei Shleifer and Robert Vishny. 1997. "Legal Determinants of External Finance", Journal of Finance 52, 1131-1150.

[16] La Porta, Raael, Florencio Lopez-de-Silanes, Andrei Shleifer and Robert Vishny. 1998. "Law and Finance", Journal of Political Economy 106, 11131155.

[17] Li, Wensen, Bingde Zhang, and Fengzhu Wang. 1990. "A Brief Discussion of the Reasons for the Antagonistic Attitude of a Party Before Execution and Measures for Preventing It", People's Judicature (Renmin Sifa in Chinese) 5 .

[18] Lieberthal, Kenneth and Michael Oksenberg. 1988. Policy Making in China: Leaders, Structures, and Processes, Princeton: Princeton University Press.

[19] McAleavy, Henry. 1967. The Modern History of China, London: Weidenfeld Goldbacks.

[20] Qian, Yishi. 1978. How China Degraded to Semi-colony, Shanghai, China: Life Book Company.

[21] Sa, Benren and Xinming Pan. 1996. Anglo-Chinese Relations in the Twentieth Century (Ershi Shiji de Zhongying Guanxi in Chinese), Shanghai, China: Shanghai People's Publishing House.

[22] Tabellini, Guido. 2007a. "Culture and Institutions: Economic Development in the Regions of Europe", working paper.

[23] Tabellini, Guido. 2007b. "Institutions and Culture", working paper.

[24] Tabellini, Guido. 2009. "The Scope of Cooperation: Values and Incentives", Quarterly Journal of Economics, forthcoming. 
[25] Tai, Yingjie. 1957. "A Discussion of Our Court's Execution Work", People's Judicial Work (Renmin Sifa Gongzuo in Chinese) 3.

[26] Tan, Tao. 1996. Zhang Taiyan, Beijing: Chinese International Broadcasting Press.

[27] Yang, Yuanhua. 2006. The History of Sino-French Relations (Zhongfa Guanxi Shi in Chinese), Shanghai, China: Shanghai People's Publishing House.

[28] Yang Zundao and Fengmei Ye. 1993. Studies on Semi-colonization of Qing Dynasty, Beijing, China: Higher Education Press.

[29] Yearbook of People's Court. 1990.

[30] Zhao, Yongchen. 1989. "A Provision Should Be Added to the Criminal Law Criminalizing Contempt of Court", Modern Jurisprudence (Xiandai Faxue in Chinese) 1.

[31] Zweigert, Konrad and Hein Kötz. 1998. An Introduction to Comparative Law, Oxford and New York: Oxford University Press, Clarendon Press. 
En Table 1, Summary statistics

\begin{tabular}{l|ccccc}
\hline Variable & Obs & Mean & Std. Dev. & Min & Max \\
\hline Value Added Ratio & 1349 & 0.487 & 0.247 & 0.006 & 1.000 \\
Contracting Institutions & 1361 & 0.634 & 0.389 & 0.000 & 1.000 \\
City Average of Contracting Institutions & 1361 & 0.634 & 0.125 & 0.444 & 0.878 \\
British Administration & 1566 & 0.510 & 0.500 & 0.000 & 1.000 \\
Firm Size & 1563 & 5.040 & 1.453 & 0.000 & 9.899 \\
Firm Age & 1566 & 2.494 & 0.777 & 1.099 & 3.970 \\
Percentage of Private Ownership & 1566 & 0.796 & 0.389 & 0.000 & 1.000 \\
Bank Loans/Financial Institutions & 1540 & 0.273 & 0.446 & 0.000 & 1.000 \\
Degree of Computerization & 1548 & 0.222 & 0.265 & 0.000 & 1.000 \\
Education & 1553 & 15.359 & 2.511 & 0.000 & 19.000 \\
Tenure & 1548 & 6.240 & 4.580 & 1.000 & 33.000 \\
Deputy CEO Before & 1548 & 0.280 & 0.449 & 0.000 & 1.000 \\
Government Cadre & 1548 & 0.036 & 0.185 & 0.000 & 1.000 \\
Party Membership & 1524 & 0.648 & 0.478 & 0.000 & 1.000 \\
Logarithm of GDP per capita & 1566 & 0.420 & 0.592 & -0.457 & 2.784 \\
Logarithm of Population & 1566 & 6.303 & 0.664 & 4.938 & 8.044 \\
Ability of Government Officials & 1566 & 0.517 & 0.084 & 0.365 & 0.649 \\
Regulation of Labor & 1566 & 0.272 & 0.097 & 0.150 & 0.500 \\
Interest Rate & 1566 & 0.055 & 0.010 & 0.034 & 0.078 \\
Financial Development & 1566 & 0.028 & 0.026 & 0.000 & 0.080 \\
Regulation of Entry & 1566 & 0.710 & 0.102 & 0.565 & 0.924 \\
Suppliers & 1509 & 0.042 & 0.199 & 0.000 & 7.100 \\
Capital Intensity & 1538 & 5.718 & 70.490 & 0.0002 & 2267.389 \\
External Finance Reliance & 1276 & 0.869 & 0.292 & 0.000 & 1.000 \\
Self-Made Input Percentage & 1459 & 0.339 & 0.401 & 0.000 & 1.000 \\
Court Litigation & 1543 & 0.044 & 0.171 & 0.000 & 1.000 \\
\hline & & & & & \\
\hline
\end{tabular}


Table 2, OLS estimates

\begin{tabular}{|c|c|c|c|c|c|c|c|}
\hline \multirow[b]{2}{*}{ Dependent Variable } & 1 & 2 & 3 & 4 & 5 & 6 & 7 \\
\hline & \multicolumn{7}{|c|}{ Value Added Ratio } \\
\hline Contracting Institutions & $\begin{array}{c}-0.053^{\star \star \star} \\
{[0.019]}\end{array}$ & $\begin{array}{c}-0.054^{\star \star \star} \\
{[0.019]}\end{array}$ & $\begin{array}{c}-0.058^{\star \star \star} \\
{[0.019]}\end{array}$ & $\begin{array}{c}-0.053^{\star \star \star} \\
{[0.020]}\end{array}$ & $\begin{array}{c}-0.053^{\star \star \star} \\
{[0.020]}\end{array}$ & $\begin{array}{c}-0.049^{\star *} \\
{[0.021]}\end{array}$ & $\begin{array}{c}-0.047^{\star \star} \\
{[0.022]}\end{array}$ \\
\hline \multicolumn{8}{|l|}{ Firm Characteristics } \\
\hline Firm Size & & & $\begin{array}{c}0.004 \\
{[0.006]}\end{array}$ & $\begin{array}{c}0.000 \\
{[0.007]}\end{array}$ & $\begin{array}{c}0.000 \\
{[0.007]}\end{array}$ & $\begin{array}{c}0.002 \\
{[0.007]}\end{array}$ & $\begin{array}{c}0.004 \\
{[0.008]}\end{array}$ \\
\hline Firm Age & & & $\begin{array}{c}0.016 \\
{[0.010]}\end{array}$ & $\begin{array}{c}0.018^{\star} \\
{[0.010]}\end{array}$ & $\begin{array}{c}0.018^{\star} \\
{[0.010]}\end{array}$ & $\begin{array}{c}0.015 \\
{[0.011]}\end{array}$ & $\begin{array}{c}0.010 \\
{[0.011]}\end{array}$ \\
\hline Percentage of Private Ownership & & & $\begin{array}{l}-0.003 \\
{[0.019]}\end{array}$ & $\begin{array}{c}0.018 \\
{[0.020]}\end{array}$ & $\begin{array}{c}0.018 \\
{[0.020]}\end{array}$ & $\begin{array}{c}0.011 \\
{[0.022]}\end{array}$ & $\begin{array}{c}0.013 \\
{[0.024]}\end{array}$ \\
\hline Bank Loans & & & $\begin{array}{c}0.002 \\
{[0.016]}\end{array}$ & $\begin{array}{l}-0.002 \\
{[0.017]}\end{array}$ & $\begin{array}{l}-0.002 \\
{[0.017]}\end{array}$ & $\begin{array}{c}0.001 \\
{[0.017]}\end{array}$ & $\begin{array}{l}-0.003 \\
{[0.019]}\end{array}$ \\
\hline Degree of Computerization & & & & $\begin{array}{l}0.060^{\star} \\
{[0.033]}\end{array}$ & $\begin{array}{l}0.060^{*} \\
{[0.033]}\end{array}$ & $\begin{array}{l}0.070 \star * \\
{[0.035]}\end{array}$ & $\begin{array}{c}0.057 \\
{[0.038]}\end{array}$ \\
\hline CEO Characteristics & & & & & & & \\
\hline Human Capital & & & & & & & \\
\hline Education & & & & $\begin{array}{l}0.006^{*} \\
{[0.003]}\end{array}$ & $\begin{array}{c}0.005 \\
{[0.003]}\end{array}$ & $\begin{array}{c}0.003 \\
{[0.003]}\end{array}$ & $\begin{array}{c}0.003 \\
{[0.004]}\end{array}$ \\
\hline Tenure & & & & $\begin{array}{c}-0.001 \\
{[0.002]}\end{array}$ & $\begin{array}{c}-0.001 \\
{[0.002]}\end{array}$ & $\begin{array}{c}0.000 \\
{[0.002]}\end{array}$ & $\begin{array}{c}0.000 \\
{[0.002]}\end{array}$ \\
\hline Deputy CEO Before & & & & $\begin{array}{c}0.011 \\
{[0.015]}\end{array}$ & $\begin{array}{c}0.007 \\
{[0.015]}\end{array}$ & $\begin{array}{c}0.009 \\
{[0.015]}\end{array}$ & $\begin{array}{c}0.009 \\
{[0.016]}\end{array}$ \\
\hline Political Capital & & & & & & & \\
\hline Government Cadre & & & & & $\begin{array}{l}-0.047 \\
{[0.047]}\end{array}$ & $\begin{array}{l}-0.046 \\
{[0.047]}\end{array}$ & $\begin{array}{l}-0.049 \\
{[0.051]}\end{array}$ \\
\hline Party Membership & & & & & $\begin{array}{l}0.035^{\star *} \\
{[0.014]}\end{array}$ & $\begin{array}{c}0.024 \\
{[0.014]}\end{array}$ & $\begin{array}{c}0.029^{*} \\
{[0.015]}\end{array}$ \\
\hline $\begin{array}{l}\text { Industry Dummy } \\
\text { City Dummy }\end{array}$ & & Yes & Yes & Yes & Yes & $\begin{array}{l}\text { Yes } \\
\text { Yes }\end{array}$ & \\
\hline Industry-city Dummy & & & & & & & Yes \\
\hline Constant & $\begin{array}{c}0.523^{\star * *} \\
{[0.015]}\end{array}$ & $\begin{array}{c}0.761^{\star * *} \\
{[0.083]}\end{array}$ & $\begin{array}{l}0.727^{\star \star \star} \\
{[0.108]}\end{array}$ & $\begin{array}{c}0.619 * * \star \\
{[0.116]}\end{array}$ & $\begin{array}{c}0.590 * * * \\
{[0.118]}\end{array}$ & $\begin{array}{c}0.547^{\star * \star} \\
{[0.123]}\end{array}$ & $\begin{array}{c}0.081 \\
{[0.084]}\end{array}$ \\
\hline Observations & 1183 & 1183 & 1167 & 1140 & 1118 & 1118 & 1118 \\
\hline R-squared & 0.0069 & 0.0374 & 0.0437 & 0.0503 & 0.0569 & 0.0836 & 0.1626 \\
\hline$p$-value for F-test & 0.0000 & 0.0000 & 0.0000 & 0.0000 & 0.0000 & 0.0000 & 0.0000 \\
\hline
\end{tabular}

Note: Standard errors, clustered at industry-city level, are reported in brackets. ${ }^{\star \star \star} p<0.01,{ }^{\star \star} p<0.05,{ }^{\star} p<0.1$. 
Table 3, GMM estimates I

\begin{tabular}{|c|c|c|c|c|}
\hline Estimation & \multicolumn{2}{|c|}{ GMM } & \multicolumn{2}{|c|}{ OLS } \\
\hline Panel A & \multicolumn{2}{|c|}{$\begin{array}{l}\text { Second Stage: Dependent } \\
\text { Variable is Value Added Ratio }\end{array}$} & \multicolumn{2}{|c|}{$\begin{array}{l}\text { Dependent Variable is } \\
\text { Value Added Ratio }\end{array}$} \\
\hline Contracting Institutions & $\begin{array}{c}-0.200^{\star *} \\
{[0.085]}\end{array}$ & $\begin{array}{l}-0.275^{\star} \\
{[0.142]}\end{array}$ & & $\begin{array}{l}-0.049^{* *} \\
{[0.020]}\end{array}$ \\
\hline City Average of Contracting Institutions & & & $\begin{array}{c}-0.200 * * \\
{[0.100]}\end{array}$ & $\begin{array}{l}-0.165 \\
{[0.100]}\end{array}$ \\
\hline \multicolumn{5}{|l|}{ Firm Characteristics } \\
\hline Firm Size & $\begin{array}{c}0.003 \\
{[0.007]}\end{array}$ & $\begin{array}{c}0.005 \\
{[0.007]}\end{array}$ & $\begin{array}{c}-0.001 \\
{[0.007]}\end{array}$ & $\begin{array}{c}0.000 \\
{[0.007]}\end{array}$ \\
\hline Firm Age & $\begin{array}{c}0.013 \\
{[0.010]}\end{array}$ & $\begin{array}{c}0.011 \\
{[0.011]}\end{array}$ & $\begin{array}{l}0.021^{\star *} \\
{[0.010]}\end{array}$ & $\begin{array}{l}0.019^{\star} \\
{[0.010]}\end{array}$ \\
\hline Percentage of Private Ownership & $\begin{array}{c}0.007 \\
{[0.023]}\end{array}$ & $\begin{array}{c}0.000 \\
{[0.026]}\end{array}$ & $\begin{array}{c}0.023 \\
{[0.020]}\end{array}$ & $\begin{array}{c}0.019 \\
{[0.020]}\end{array}$ \\
\hline Bank Loans & $\begin{array}{c}0.006 \\
{[0.018]}\end{array}$ & $\begin{array}{c}0.011 \\
{[0.020]}\end{array}$ & $\begin{array}{c}-0.004 \\
{[0.016]}\end{array}$ & $\begin{array}{c}-0.001 \\
{[0.017]}\end{array}$ \\
\hline Degree of Computerization & $\begin{array}{l}0.080 * * \\
{[0.035]}\end{array}$ & $\begin{array}{l}0.092^{\star *} \\
{[0.038]}\end{array}$ & $\begin{array}{c}0.054 \\
{[0.035]}\end{array}$ & $\begin{array}{l}0.061^{*} \\
{[0.034]}\end{array}$ \\
\hline \multicolumn{5}{|l|}{ CEO Characteristics } \\
\hline Education & $\begin{array}{c}0.004 \\
{[0.004]}\end{array}$ & $\begin{array}{c}0.003 \\
{[0.004]}\end{array}$ & $\begin{array}{c}0.005^{\star} \\
{[0.003]}\end{array}$ & $\begin{array}{c}0.005 \\
{[0.003]}\end{array}$ \\
\hline Tenure & $\begin{array}{c}0.000 \\
{[0.002]}\end{array}$ & $\begin{array}{c}0.000 \\
{[0.002]}\end{array}$ & $\begin{array}{c}-0.001 \\
{[0.002]}\end{array}$ & $\begin{array}{c}-0.001 \\
{[0.002]}\end{array}$ \\
\hline Deputy CEO Before & $\begin{array}{c}0.005 \\
{[0.015]}\end{array}$ & $\begin{array}{c}0.004 \\
{[0.016]}\end{array}$ & $\begin{array}{c}0.010 \\
{[0.015]}\end{array}$ & $\begin{array}{c}0.008 \\
{[0.015]}\end{array}$ \\
\hline Political Capital & & & & \\
\hline Government Cadre & $\begin{array}{c}-0.052 \\
{[0.047]}\end{array}$ & $\begin{array}{c}-0.055 \\
{[0.048]}\end{array}$ & $\begin{array}{c}-0.046 \\
{[0.047]}\end{array}$ & $\begin{array}{c}-0.047 \\
{[0.047]}\end{array}$ \\
\hline Party Membership & $\begin{array}{l}0.033^{* *} \\
{[0.014]}\end{array}$ & $\begin{array}{l}0.031^{*} \\
{[0.016]}\end{array}$ & $\begin{array}{l}0.034^{\star *} \\
{[0.014]}\end{array}$ & $\begin{array}{l}0.033^{* *} \\
{[0.014]}\end{array}$ \\
\hline $\begin{array}{l}\text { Industry Dummy } \\
\text { City Characteristics }\end{array}$ & Yes & Yes & Yes & Yes \\
\hline Logarithm of GDP per capita & $\begin{array}{c}-0.002 \\
{[0.022]}\end{array}$ & $\begin{array}{c}-0.004 \\
{[0.023]}\end{array}$ & $\begin{array}{c}0.000 \\
{[0.022]}\end{array}$ & $\begin{array}{l}-0.001 \\
{[0.022]}\end{array}$ \\
\hline Logarithm of Population & $\begin{array}{c}0.028 \\
{[0.021]}\end{array}$ & $\begin{array}{c}0.028 \\
{[0.021]}\end{array}$ & $\begin{array}{c}0.026 \\
{[0.019]}\end{array}$ & $\begin{array}{c}0.027 \\
{[0.020]}\end{array}$ \\
\hline Ability of Government Officials & & $\begin{array}{c}0.150 \\
{[0.187]}\end{array}$ & $\begin{array}{c}0.070 \\
{[0.139]}\end{array}$ & $\begin{array}{c}0.084 \\
{[0.143]}\end{array}$ \\
\hline Constant & $\begin{array}{c}0.311^{\star * *} \\
{[0.113]}\end{array}$ & $\begin{array}{l}0.299 * * \\
{[0.121]}\end{array}$ & $\begin{array}{l}0.479 * * * \\
{[0.150]}\end{array}$ & $\begin{array}{c}0.492^{\star * *} \\
{[0.149]}\end{array}$ \\
\hline Panel B & First Stage: & ent Variable & & \\
\hline
\end{tabular}




\begin{tabular}{l|cc|c} 
& \multicolumn{2}{|c|}{ is Contracting Institutions } & \\
City Average of Contracting Institutions & $0.852^{\star \star \star}$ & $0.729^{\star \star \star}$ & \\
Anderson Canonical Correlation LR Statistic & {$[0.110]$} & {$[0.113]$} & \\
Shea Partial R-squared & $0.44]^{\star \star \star}$ & {$[26.97]^{\star \star \star}$} & \\
Cragg-Donald F-statistic & {$[58.02]$} & 0.0243 & \\
\hline Panel C & Corresponding OLS estimates & \\
Contracting Institutions & $-0.056^{\star \star \star}$ & $-0.054^{\star \star \star}$ & \\
& {$[0.020]$} & {$[0.020]$} & \\
Dubin-Wu-Hausman Test & {$[2.59]$} & {$[2.55]$} & \\
\hline Observations & 1118 & 1118 & 1118 \\
\hline
\end{tabular}

Note: In Columns 1-2, the first stage of the GMM estimates and the corresponding OLS estimates include the same control variables as in the second stage of the GMM estimates but the estimated coefficients of these control variables are not reported to save space (available upon request). Standard errors, clustered at industry-city level, are reported in brackets. ${ }^{\star *} p<0.01,{ }^{* \star} p<0.05,{ }^{*} p<0.1$. 
Table 4, GMM estimates II

\begin{tabular}{|c|c|c|c|c|c|c|}
\hline & 1 & 2 & 3 & 4 & 5 & 6 \\
\hline Panel A & \multicolumn{6}{|c|}{ Second Stage: Dependent Variable is Value Added Ratio } \\
\hline Contracting Institutions & $\begin{array}{l}-0.527^{\star} \\
{[0.309]}\end{array}$ & $\begin{array}{c}-0.418^{\star *} \\
{[0.196]}\end{array}$ & $\begin{array}{c}-0.467^{\star *} \\
{[0.211]}\end{array}$ & $\begin{array}{c}-0.494^{\star \star} \\
{[0.210]}\end{array}$ & $\begin{array}{c}-0.414^{\star *} \\
{[0.202]}\end{array}$ & $\begin{array}{l}-0.336^{\star} \\
{[0.180]}\end{array}$ \\
\hline Firm Characteristics & & & & & & \\
\hline Firm Size & $\begin{array}{c}0.010 \\
{[0.010]}\end{array}$ & $\begin{array}{c}0.008 \\
{[0.009]}\end{array}$ & $\begin{array}{c}0.01 \\
{[0.009]}\end{array}$ & $\begin{array}{c}0.011 \\
{[0.010]}\end{array}$ & $\begin{array}{c}0.010 \\
{[0.009]}\end{array}$ & $\begin{array}{c}0.009 \\
{[0.008]}\end{array}$ \\
\hline Firm Age & $\begin{array}{c}0.002 \\
{[0.017]}\end{array}$ & $\begin{array}{c}0.006 \\
{[0.013]}\end{array}$ & $\begin{array}{c}0.001 \\
{[0.015]}\end{array}$ & $\begin{array}{c}0.001 \\
{[0.016]}\end{array}$ & $\begin{array}{c}0.004 \\
{[0.015]}\end{array}$ & $\begin{array}{c}0.006 \\
{[0.013]}\end{array}$ \\
\hline Percentage of Private Ownership & $\begin{array}{c}-0.017 \\
{[0.037]}\end{array}$ & $\begin{array}{c}-0.012 \\
{[0.031]}\end{array}$ & $\begin{array}{l}-0.013 \\
{[0.032]}\end{array}$ & $\begin{array}{l}-0.016 \\
{[0.033]}\end{array}$ & $\begin{array}{l}-0.009 \\
{[0.031]}\end{array}$ & $\begin{array}{l}-0.003 \\
{[0.028]}\end{array}$ \\
\hline Bank Loans & $\begin{array}{c}0.023 \\
{[0.025]}\end{array}$ & $\begin{array}{c}0.019 \\
{[0.021]}\end{array}$ & $\begin{array}{c}0.022 \\
{[0.022]}\end{array}$ & $\begin{array}{c}0.023 \\
{[0.023]}\end{array}$ & $\begin{array}{c}0.023 \\
{[0.022]}\end{array}$ & $\begin{array}{c}0.018 \\
{[0.021]}\end{array}$ \\
\hline Degree of Computerization & $\begin{array}{l}0.119^{\star *} \\
{[0.050]}\end{array}$ & $\begin{array}{c}0.113^{\star \star \star} \\
{[0.042]}\end{array}$ & $\begin{array}{c}0.117^{\star \star \star} \\
{[0.042]}\end{array}$ & $\begin{array}{c}0.123^{\star \star \star} \\
{[0.043]}\end{array}$ & $\begin{array}{c}0.111^{\star \star \star} \\
{[0.043]}\end{array}$ & $\begin{array}{l}0.102^{\star \star} \\
{[0.041]}\end{array}$ \\
\hline $\begin{array}{l}\text { CEO Characteristics } \\
\text { Human Capital }\end{array}$ & & & & & & \\
\hline Education & $\begin{array}{c}0.001 \\
{[0.005]}\end{array}$ & $\begin{array}{c}0.002 \\
{[0.005]}\end{array}$ & $\begin{array}{c}0.001 \\
{[0.005]}\end{array}$ & $\begin{array}{c}0.001 \\
{[0.005]}\end{array}$ & $\begin{array}{c}0.002 \\
{[0.005]}\end{array}$ & $\begin{array}{c}0.002 \\
{[0.004]}\end{array}$ \\
\hline Tenure & $\begin{array}{c}0.000 \\
{[0.002]}\end{array}$ & $\begin{array}{c}0.000 \\
{[0.002]}\end{array}$ & $\begin{array}{c}0.000 \\
{[0.002]}\end{array}$ & $\begin{array}{c}0.000 \\
{[0.002]}\end{array}$ & $\begin{array}{c}0.000 \\
{[0.002]}\end{array}$ & $\begin{array}{c}0.000 \\
{[0.002]}\end{array}$ \\
\hline Deputy CEO Before & $\begin{array}{c}-0.001 \\
{[0.019]}\end{array}$ & $\begin{array}{c}0.001 \\
{[0.018]}\end{array}$ & $\begin{array}{l}-0.001 \\
{[0.019]}\end{array}$ & $\begin{array}{c}-0.002 \\
{[0.019]}\end{array}$ & $\begin{array}{c}0.000 \\
{[0.018]}\end{array}$ & $\begin{array}{c}0.002 \\
{[0.017]}\end{array}$ \\
\hline Political Capital & & & & & & \\
\hline Government Cadre & $\begin{array}{l}-0.058 \\
{[0.054]}\end{array}$ & $\begin{array}{c}-0.06 \\
{[0.051]}\end{array}$ & $\begin{array}{l}-0.064 \\
{[0.052]}\end{array}$ & $\begin{array}{l}-0.065 \\
{[0.053]}\end{array}$ & $\begin{array}{l}-0.063 \\
{[0.050]}\end{array}$ & $\begin{array}{l}-0.061 \\
{[0.048]}\end{array}$ \\
\hline Party Membership & $\begin{array}{c}0.029 \\
{[0.020]}\end{array}$ & $\begin{array}{c}0.028 \\
{[0.019]}\end{array}$ & $\begin{array}{c}0.024 \\
{[0.020]}\end{array}$ & $\begin{array}{c}0.023 \\
{[0.021]}\end{array}$ & $\begin{array}{c}0.023 \\
{[0.019]}\end{array}$ & $\begin{array}{c}0.024 \\
{[0.017]}\end{array}$ \\
\hline $\begin{array}{l}\text { Industry Dummy } \\
\text { City Characteristics }\end{array}$ & Yes & Yes & Yes & Yes & Yes & Yes \\
\hline Logarithm of GDP per capita & $\begin{array}{c}0.024 \\
{[0.034]}\end{array}$ & $\begin{array}{c}0.000 \\
{[0.025]}\end{array}$ & $\begin{array}{c}0.033 \\
{[0.031]}\end{array}$ & $\begin{array}{c}0.027 \\
{[0.035]}\end{array}$ & $\begin{array}{c}0.033 \\
{[0.032]}\end{array}$ & $\begin{array}{c}0.057 \\
{[0.037]}\end{array}$ \\
\hline Logarithm of Population & $\begin{array}{c}0.073 \\
{[0.047]}\end{array}$ & $\begin{array}{c}0.038 \\
{[0.025]}\end{array}$ & $\begin{array}{l}0.059^{* *} \\
{[0.029]}\end{array}$ & $\begin{array}{l}0.056^{*} \\
{[0.031]}\end{array}$ & $\begin{array}{l}0.063^{* *} \\
{[0.029]}\end{array}$ & $\begin{array}{l}0.073^{\star *} \\
{[0.030]}\end{array}$ \\
\hline Ability of Government Officials & & $\begin{array}{c}0.285 \\
{[0.234]}\end{array}$ & $\begin{array}{c}0.241 \\
{[0.232]}\end{array}$ & $\begin{array}{c}0.310 \\
{[0.258]}\end{array}$ & $\begin{array}{c}0.183 \\
{[0.254]}\end{array}$ & $\begin{array}{c}0.002 \\
{[0.242]}\end{array}$ \\
\hline Regulation of Labor & & & $\begin{array}{l}-0.203^{\star} \\
{[0.113]}\end{array}$ & $\begin{array}{l}-0.190 \\
{[0.117]}\end{array}$ & $\begin{array}{l}-0.184^{*} \\
{[0.105]}\end{array}$ & $\begin{array}{l}-0.221^{\text {** }} \\
{[0.101]}\end{array}$ \\
\hline Interest Rate & & & & $\begin{array}{l}-0.629 \\
{[1.106]}\end{array}$ & $\begin{array}{l}-0.901 \\
{[1.072]}\end{array}$ & $\begin{array}{l}-0.931 \\
{[0.982]}\end{array}$ \\
\hline Financial Development & & & & & $\begin{array}{l}-0.156 \\
{[0.096]}\end{array}$ & $\begin{array}{l}-0.215^{\star \star} \\
{[0.102]}\end{array}$ \\
\hline Regulation of Entry & & & & & & -0.500 \\
\hline
\end{tabular}




\begin{tabular}{|c|c|c|c|c|c|c|}
\hline Constant & $\begin{array}{l}0.292^{* *} \\
{[0.139]}\end{array}$ & $\begin{array}{l}0.283^{* *} \\
{[0.134]}\end{array}$ & $\begin{array}{l}0.358^{\star *} \\
{[0.149]}\end{array}$ & $\begin{array}{l}0.396^{* *} \\
{[0.167]}\end{array}$ & $\begin{array}{l}0.393^{\star *} \\
{[0.161]}\end{array}$ & $\begin{array}{c}{[0.468]} \\
0.398^{\star \star \star} \\
{[0.149]}\end{array}$ \\
\hline Panel B & \multicolumn{6}{|c|}{ First Stage: Dependent Variable is Contracting Institutions } \\
\hline British Administration & $\begin{array}{l}0.073^{\star *} \\
{[0.033]}\end{array}$ & $\begin{array}{l}0.102^{\star \star \star} \\
{[0.027]}\end{array}$ & $\begin{array}{l}0.102^{\star \star \star} \\
{[0.027]}\end{array}$ & $\begin{array}{l}0.110^{\star * *} \\
{[0.026]}\end{array}$ & $\begin{array}{l}0.118^{\star * \star} \\
{[0.027]}\end{array}$ & $\begin{array}{c}0.139^{\star \star \star} \\
{[0.031]}\end{array}$ \\
\hline $\begin{array}{l}\text { Anderson Canonical Correlation LR } \\
\text { Statistic }\end{array}$ & {$[7.43]^{\star \star \star}$} & {$[15.20]^{\star * *}$} & {$[14.78]^{\star \star \star}$} & {$[16.55]^{\star \star *}$} & {$[17.57]^{\star \star \star}$} & {$[19.01]^{\star \star *}$} \\
\hline $\begin{array}{l}\text { Shea Partial R-squared } \\
\text { Cragg-Donald F-statistic }\end{array}$ & $\begin{array}{l}0.075 \\
{[7.28]}\end{array}$ & $\begin{array}{l}0.0148 \\
{[15.21]}\end{array}$ & $\begin{array}{l}0.0145 \\
{[14.84]}\end{array}$ & $\begin{array}{l}0.0159 \\
{[16.69]}\end{array}$ & $\begin{array}{l}0.0166 \\
{[17.49]}\end{array}$ & $\begin{array}{l}0.0187 \\
{[18.68]}\end{array}$ \\
\hline Panel C & \multicolumn{6}{|c|}{ Corresponding OLS estimates } \\
\hline Contracting Institutions & $\begin{array}{c}-0.056^{\star \star *} \\
{[0.020]} \\
{[3.37]^{\star \star}}\end{array}$ & $\begin{array}{c}-0.054^{\star \star \star} \\
{[0.020]} \\
{[3.96]^{\star \star}}\end{array}$ & $\begin{array}{c}-0.055^{\star \star \star} \\
{[0.020]} \\
{[5.03]^{\star \star}}\end{array}$ & $\begin{array}{c}-0.055^{\star \star \star} \\
{[0.020]} \\
{[5.52]^{\star \star}}\end{array}$ & $\begin{array}{c}-0.054^{\star \star \star} \\
{[0.020]} \\
{[4.05]^{\star \star}}\end{array}$ & $\begin{array}{c}-0.054^{\star \star *} \\
{[0.020]} \\
{[2.98]^{\star}}\end{array}$ \\
\hline Observations & 1118 & 1118 & 1118 & 1118 & 1118 & 1118 \\
\hline
\end{tabular}

Note: The first stage of the GMM estimates and the corresponding OLS estimates include the same control variables as in the second stage of the GMM estimates but the estimated coefficients of these control variables are not reported to save space (available upon request). Standard errors, clustered at industry-city level, are reported in brackets. ${ }^{\star *} p<0.01,{ }^{* *} p<0.05$, * $\mathrm{p}<0.1$. 
Table 5, Heterogeneous response estimates

\begin{tabular}{|c|c|c|}
\hline \multirow{3}{*}{$\begin{array}{l}\text { Dependent Variable } \\
\text { Contracting Institutions }\end{array}$} & 1 & 2 \\
\hline & \multicolumn{2}{|c|}{ Value Added Ratio } \\
\hline & $\begin{array}{c}-0.047 * * \\
{[0.022]}\end{array}$ & $\begin{array}{c}-0.051^{* *} \\
{[0.021]}\end{array}$ \\
\hline Contracting Institutions * Suppliers & $\begin{array}{l}-0.231^{*} \\
{[0.136]}\end{array}$ & \\
\hline Suppliers & $\begin{array}{c}0.005 \\
{[0.010]}\end{array}$ & \\
\hline Contacting Institutions * Capital Intensity & & $\begin{array}{l}-0.002 * \\
{[0.001]}\end{array}$ \\
\hline Capital Intensity & & $\begin{array}{c}0.002 * * * \\
{[0.001]}\end{array}$ \\
\hline Firm Characteristics & & \\
\hline Firm Size & $\begin{array}{c}0.007 \\
{[0.008]}\end{array}$ & $\begin{array}{c}0.004 \\
{[0.007]}\end{array}$ \\
\hline Firm Age & $\begin{array}{c}0.008 \\
{[0.012]}\end{array}$ & $\begin{array}{c}0.010 \\
{[0.011]}\end{array}$ \\
\hline Percentage of Private Ownership & $\begin{array}{c}0.012 \\
{[0.024]}\end{array}$ & $\begin{array}{c}0.013 \\
{[0.024]}\end{array}$ \\
\hline Bank Loans & $\begin{array}{c}-0.005 \\
{[0.020]}\end{array}$ & $\begin{array}{c}0.000 \\
{[0.020]}\end{array}$ \\
\hline Degree of Computerization & $\begin{array}{c}0.058 \\
{[0.039]}\end{array}$ & $\begin{array}{c}0.058 \\
{[0.038]}\end{array}$ \\
\hline $\begin{array}{l}\text { CEO Characteristics } \\
\text { Human Capital }\end{array}$ & & \\
\hline Education & $\begin{array}{c}0.003 \\
{[0.004]}\end{array}$ & $\begin{array}{c}0.003 \\
{[0.003]}\end{array}$ \\
\hline Tenure & $\begin{array}{c}0.000 \\
{[0.002]}\end{array}$ & $\begin{array}{c}0.000 \\
{[0.002]}\end{array}$ \\
\hline Deputy CEO Before & $\begin{array}{c}0.008 \\
{[0.016]}\end{array}$ & $\begin{array}{c}0.011 \\
{[0.016]}\end{array}$ \\
\hline Political Capital & & \\
\hline Government Cadre & $\begin{array}{c}-0.044 \\
{[0.050]}\end{array}$ & $\begin{array}{l}-0.038 \\
{[0.051]}\end{array}$ \\
\hline Party Membership & $\begin{array}{l}0.027^{*} \\
{[0.015]}\end{array}$ & $\begin{array}{l}0.029 * \\
{[0.015]}\end{array}$ \\
\hline Industry-city Dummy & Yes & Yes \\
\hline Constant & $\begin{array}{c}0.050 \\
{[0.085]}\end{array}$ & $\begin{array}{c}0.049 \\
{[0.083]}\end{array}$ \\
\hline Observations & 1101 & 1110 \\
\hline R-squared & 0.1662 & 0.1685 \\
\hline $\mathrm{p}$-value for F-test & 0.0000 & 0.0000 \\
\hline
\end{tabular}


Note: Standard errors, clustered at industry-city level, are reported in brackets. ${ }^{* * *} \mathrm{p}<0.01,{ }^{* *} \mathrm{p}<0.05,{ }^{*} \mathrm{p}<0.1$. 
Table 6, Alternative measures

\begin{tabular}{|c|c|c|c|c|}
\hline $\begin{array}{l}\text { Estimation } \\
\text { Dependent Variable }\end{array}$ & $\begin{array}{c}1 \\
\text { OLS } \\
\text { Self-Made Ir }\end{array}$ & $\begin{array}{c}2 \\
\text { GMM } \\
\text { Percentage } \\
\end{array}$ & $\begin{array}{c}3 \\
\text { OLS } \\
\text { Value A }\end{array}$ & $\begin{array}{c}4 \\
\text { GMM } \\
\text { Ratio }\end{array}$ \\
\hline Contracting Institutions & $\begin{array}{l}-0.030 \\
{[0.032]}\end{array}$ & $\begin{array}{c}-0.239 * * \\
{[0.112]}\end{array}$ & & \\
\hline Court Litigation & & & $\begin{array}{c}-0.078^{\star * *} \\
{[0.024]}\end{array}$ & $\begin{array}{l}-0.305 \\
{[0.424]}\end{array}$ \\
\hline Firm Characteristics & & & & \\
\hline Firm Size & $\begin{array}{c}0.012 \\
{[0.008]}\end{array}$ & $\begin{array}{l}0.017^{*} \\
{[0.008]}\end{array}$ & $\begin{array}{l}-0.001 \\
{[0.006]}\end{array}$ & $\begin{array}{c}0.001 \\
{[0.007]}\end{array}$ \\
\hline Firm Age & $\begin{array}{c}0.023 \\
{[0.019]}\end{array}$ & $\begin{array}{c}0.018 \\
{[0.020]}\end{array}$ & $\begin{array}{l}0.023^{* *} \\
{[0.010]}\end{array}$ & $\begin{array}{l}0.025^{\star \star} \\
{[0.011]}\end{array}$ \\
\hline Percentage of Private Ownership & $\begin{array}{c}0.048 \\
{[0.031]}\end{array}$ & $\begin{array}{c}0.034 \\
{[0.034]}\end{array}$ & $\begin{array}{c}0.013 \\
{[0.020]}\end{array}$ & $\begin{array}{c}0.012 \\
{[0.020]}\end{array}$ \\
\hline Bank Loans & $\begin{array}{c}0.018 \\
{[0.026]}\end{array}$ & $\begin{array}{c}0.025 \\
{[0.027]}\end{array}$ & $\begin{array}{l}-0.008 \\
{[0.015]}\end{array}$ & $\begin{array}{l}-0.004 \\
{[0.018]}\end{array}$ \\
\hline Degree of Computerization & $\begin{array}{l}-0.009 \\
{[0.049]}\end{array}$ & $\begin{array}{c}0.017 \\
{[0.055]}\end{array}$ & $\begin{array}{l}0.069^{\star *} \\
{[0.030]}\end{array}$ & $\begin{array}{l}0.070^{* *} \\
{[0.028]}\end{array}$ \\
\hline $\begin{array}{l}\text { CEO Characteristics } \\
\text { Human Capital }\end{array}$ & & & & \\
\hline Education & $\begin{array}{l}0.008^{*} \\
{[0.005]}\end{array}$ & $\begin{array}{c}0.007 \\
{[0.005]}\end{array}$ & $\begin{array}{c}0.005 \\
{[0.003]}\end{array}$ & $\begin{array}{c}0.005 \\
{[0.003]}\end{array}$ \\
\hline Tenure & $\begin{array}{c}0.004 \\
{[0.003]}\end{array}$ & $\begin{array}{c}0.004 \\
{[0.003]}\end{array}$ & $\begin{array}{l}-0.002 \\
{[0.002]}\end{array}$ & $\begin{array}{l}-0.002 \\
{[0.002]}\end{array}$ \\
\hline Deputy CEO Before & $\begin{array}{c}0.025 \\
{[0.023]}\end{array}$ & $\begin{array}{c}0.021 \\
{[0.024]}\end{array}$ & $\begin{array}{c}0.012 \\
{[0.014]}\end{array}$ & $\begin{array}{c}0.012 \\
{[0.014]}\end{array}$ \\
\hline Political Capital & & & & \\
\hline Government Cadre & $\begin{array}{c}-0.146^{\star \star \star} \\
{[0.052]}\end{array}$ & $\begin{array}{c}-0.154^{\star \star \star} \\
{[0.055]}\end{array}$ & $\begin{array}{c}-0.047 \\
{[0.048]}\end{array}$ & $\begin{array}{c}-0.041 \\
{[0.051]}\end{array}$ \\
\hline Party Membership & $\begin{array}{c}-0.008 \\
{[0.028]}\end{array}$ & $\begin{array}{l}-0.010 \\
{[0.027]}\end{array}$ & $\begin{array}{c}0.041 * * * \\
{[0.013]}\end{array}$ & $\begin{array}{c}0.045^{\star \star \star} \\
{[0.013]}\end{array}$ \\
\hline $\begin{array}{l}\text { Industry Dummy } \\
\text { City Characteristics }\end{array}$ & Yes & Yes & Yes & Yes \\
\hline Logarithm of GDP per capita & $\begin{array}{l}-0.031 \\
{[0.025]}\end{array}$ & $\begin{array}{l}-0.010 \\
{[0.031]}\end{array}$ & $\begin{array}{l}-0.013 \\
{[0.018]}\end{array}$ & $\begin{array}{l}-0.003 \\
{[0.024]}\end{array}$ \\
\hline Logarithm of Population & $\begin{array}{l}-0.009 \\
{[0.021]}\end{array}$ & $\begin{array}{c}0.022 \\
{[0.030]}\end{array}$ & $\begin{array}{c}0.01 \\
{[0.015]}\end{array}$ & $\begin{array}{c}0.018 \\
{[0.021]}\end{array}$ \\
\hline Constant & $\begin{array}{c}0.153 \\
{[0.170]}\end{array}$ & $\begin{array}{c}0.233 \\
{[0.173]}\end{array}$ & $\begin{array}{l}0.316^{\star \star} \\
{[0.122]}\end{array}$ & $\begin{array}{l}0.250^{\star *} \\
{[0.119]}\end{array}$ \\
\hline $\begin{array}{l}\text { Tests } \\
\text { Anderson Canonical Correlation LR Statistic } \\
\text { Shea Partial R-squared } \\
\text { Cragg-Donald F-statistic }\end{array}$ & & $\begin{array}{c}{[48.52]^{\star \star \star}} \\
0.0475 \\
{[57.55]}\end{array}$ & & $\begin{array}{c}{[9.16]^{\star \star \star}} \\
0.081 \\
{[9.26]}\end{array}$ \\
\hline
\end{tabular}




\begin{tabular}{l|cc|cc} 
Dubin-Wu-Hausman Test & & {$[3.29]^{*}$} & {$[0.29]$} \\
\hline Observations & 1222 & 1222 & 1251 & 1251 \\
\hline
\end{tabular}

Note: Standard errors, clustered at industry-city level, are reported in brackets. ${ }^{\star \star \star} p<0.01,{ }^{\star \star} p<0.05,{ }^{\star} p<0.1$. 
Table 7, Sub-samples

\begin{tabular}{|c|c|c|c|c|c|c|}
\hline $\begin{array}{l}\text { Estimation } \\
\text { Sub-sample } \\
\text { Dependent Variable }\end{array}$ & $\begin{array}{c}1 \\
\text { OLS } \\
\text { Firms with F } \\
\text { Value } A\end{array}$ & $\begin{array}{c}2 \\
\text { GMM } \\
\text { d Business } \\
\text { Ratio }\end{array}$ & $\begin{array}{l}3 \\
\text { OLS } \\
\text { Priv } \\
\text { Value } f\end{array}$ & $\begin{array}{c}4 \\
\text { GMM } \\
\text {-irms } \\
\text { ed Ratio }\end{array}$ & $\begin{array}{c}\text { Small Firms } \\
\text { Value Added Ratio }\end{array}$ & $\begin{array}{c}6 \\
\text { GMM } \\
\text { irms } \\
\text { ed Ratio }\end{array}$ \\
\hline Contracting Institutions & $\begin{array}{c}-0.088^{\star \star \star} \\
{[0.029]}\end{array}$ & $\begin{array}{c}-0.210^{\star \star} \\
{[0.088]}\end{array}$ & $\begin{array}{c}-0.075^{\star \star \star} \\
{[0.023]}\end{array}$ & $\begin{array}{c}-0.254^{\star \star} \\
{[0.110]}\end{array}$ & $\begin{array}{c}-0.057^{\star \star \star} \\
{[0.019]}\end{array}$ & $\begin{array}{c}-0.227^{\star \star} \\
{[0.088]}\end{array}$ \\
\hline \multicolumn{7}{|l|}{ Firm Characteristics } \\
\hline Firm Size & $\begin{array}{c}-0.004 \\
{[0.010]}\end{array}$ & $\begin{array}{l}-0.005 \\
{[0.010]}\end{array}$ & $\begin{array}{c}0.004 \\
{[0.008]}\end{array}$ & $\begin{array}{c}0.005 \\
{[0.007]}\end{array}$ & $\begin{array}{c}-0.002 \\
{[0.008]}\end{array}$ & $\begin{array}{c}0.003 \\
{[0.008]}\end{array}$ \\
\hline Firm Age & $\begin{array}{c}0.022 \\
{[0.015]}\end{array}$ & $\begin{array}{c}0.020 \\
{[0.014]}\end{array}$ & $\begin{array}{c}0.010 \\
{[0.013]}\end{array}$ & $\begin{array}{c}0.004 \\
{[0.013]}\end{array}$ & $\begin{array}{l}0.021^{*} \\
{[0.011]}\end{array}$ & $\begin{array}{c}0.015 \\
{[0.011]}\end{array}$ \\
\hline Percentage of Private Ownership & $\begin{array}{c}0.019 \\
{[0.029]}\end{array}$ & $\begin{array}{c}0.005 \\
{[0.032]}\end{array}$ & $\begin{array}{c}-2.067 \\
{[1.719]}\end{array}$ & $\begin{array}{l}-2.726 \\
{[1.795]}\end{array}$ & $\begin{array}{c}0.000 \\
{[0.022]}\end{array}$ & $\begin{array}{l}-0.014 \\
{[0.025]}\end{array}$ \\
\hline Bank Loans & $\begin{array}{c}0.001 \\
{[0.021]}\end{array}$ & $\begin{array}{c}0.009 \\
{[0.022]}\end{array}$ & $\begin{array}{c}0.003 \\
{[0.020]}\end{array}$ & $\begin{array}{c}0.012 \\
{[0.021]}\end{array}$ & $\begin{array}{c}0.002 \\
{[0.018]}\end{array}$ & $\begin{array}{c}0.012 \\
{[0.019]}\end{array}$ \\
\hline Degree of Computerization & $\begin{array}{l}0.100 * \star \\
{[0.044]}\end{array}$ & $\begin{array}{l}0.116^{\star \star \star} \\
{[0.044]}\end{array}$ & $\begin{array}{c}0.039 \\
{[0.038]}\end{array}$ & $\begin{array}{c}0.065 \\
{[0.040]}\end{array}$ & $\begin{array}{c}0.061 \\
{[0.037]}\end{array}$ & $\begin{array}{l}0.084^{\star *} \\
{[0.038]}\end{array}$ \\
\hline $\begin{array}{l}\text { CEO Characteristics } \\
\text { Human Capital }\end{array}$ & & & & & & \\
\hline Education & $\begin{array}{c}0.005 \\
{[0.004]}\end{array}$ & $\begin{array}{c}0.004 \\
{[0.004]}\end{array}$ & $\begin{array}{l}0.007^{\star} \\
{[0.004]}\end{array}$ & $\begin{array}{c}0.005 \\
{[0.004]}\end{array}$ & $\begin{array}{c}0.006 \\
{[0.004]}\end{array}$ & $\begin{array}{c}0.004 \\
{[0.004]}\end{array}$ \\
\hline Tenure & $\begin{array}{c}-0.002 \\
{[0.002]}\end{array}$ & $\begin{array}{l}-0.002 \\
{[0.002]}\end{array}$ & $\begin{array}{l}-0.001 \\
{[0.002]}\end{array}$ & $\begin{array}{c}-0.001 \\
{[0.002]}\end{array}$ & $\begin{array}{l}-0.001 \\
{[0.002]}\end{array}$ & $\begin{array}{c}-0.001 \\
{[0.002]}\end{array}$ \\
\hline Deputy CEO Before & $\begin{array}{c}0.025 \\
{[0.018]}\end{array}$ & $\begin{array}{c}0.025 \\
{[0.019]}\end{array}$ & $\begin{array}{c}0.001 \\
{[0.018]}\end{array}$ & $\begin{array}{c}-0.004 \\
{[0.019]}\end{array}$ & $\begin{array}{c}-0.001 \\
{[0.018]}\end{array}$ & $\begin{array}{l}-0.005 \\
{[0.018]}\end{array}$ \\
\hline Political Capital & & & & & & \\
\hline Government Cadre & $\begin{array}{l}-0.066 \\
{[0.057]}\end{array}$ & $\begin{array}{l}-0.052 \\
{[0.058]}\end{array}$ & $\begin{array}{l}-0.061 \\
{[0.059]}\end{array}$ & $\begin{array}{l}-0.063 \\
{[0.057]}\end{array}$ & $\begin{array}{l}-0.081 \\
{[0.050]}\end{array}$ & $\begin{array}{l}-0.087^{\star} \\
{[0.050]}\end{array}$ \\
\hline
\end{tabular}




\begin{tabular}{|c|c|c|c|c|c|c|}
\hline Party Membership & $\begin{array}{l}0.051^{\star *} \\
{[0.020]}\end{array}$ & $\begin{array}{l}0.049^{\star *} \\
{[0.020]}\end{array}$ & $\begin{array}{c}0.040^{\star \star *} \\
{[0.015]}\end{array}$ & $\begin{array}{l}0.039 * \star \\
{[0.016]}\end{array}$ & $\begin{array}{c}0.038^{\star \star \star} \\
{[0.014]}\end{array}$ & $\begin{array}{l}0.036^{\star \star} \\
{[0.015]}\end{array}$ \\
\hline $\begin{array}{l}\text { Industry Dummy } \\
\text { City Characteristics }\end{array}$ & Yes & Yes & Yes & Yes & Yes & Yes \\
\hline Logarithm of GDP per capita & $\begin{array}{c}0.005 \\
{[0.024]}\end{array}$ & $\begin{array}{c}0.02 \\
{[0.025]}\end{array}$ & $\begin{array}{l}-0.002 \\
{[0.023]}\end{array}$ & $\begin{array}{c}0.016 \\
{[0.027]}\end{array}$ & $\begin{array}{l}-0.018 \\
{[0.024]}\end{array}$ & $\begin{array}{l}-0.002 \\
{[0.025]}\end{array}$ \\
\hline Logarithm of Population & $\begin{array}{c}0.016 \\
{[0.020]}\end{array}$ & $\begin{array}{c}0.034 \\
{[0.023]}\end{array}$ & $\begin{array}{c}0.016 \\
{[0.021]}\end{array}$ & $\begin{array}{c}0.044 \\
{[0.028]}\end{array}$ & $\begin{array}{c}0.009 \\
{[0.018]}\end{array}$ & $\begin{array}{c}0.032 \\
{[0.023]}\end{array}$ \\
\hline Constant & $\begin{array}{l}0.324^{\star \star} \\
{[0.156]}\end{array}$ & $\begin{array}{l}0.292^{\star \star} \\
{[0.133]}\end{array}$ & $\begin{array}{c}2.55 \\
{[1.719]}\end{array}$ & $\begin{array}{l}2.972^{\star} \\
{[1.789]}\end{array}$ & $\begin{array}{l}0.376^{\star \star} \\
{[0.146]}\end{array}$ & $\begin{array}{l}0.323^{\star \star} \\
{[0.126]}\end{array}$ \\
\hline $\begin{array}{l}\text { Tests } \\
\text { Anderson Canonical Correlation LR Statistic } \\
\text { Shea Partial R-squared } \\
\text { Cragg-Donald F-statistic } \\
\text { Dubin-Wu-Hausman Test }\end{array}$ & & $\begin{array}{c}{[38.96]^{\star \star \star}} \\
0.671 \\
{[51.59]} \\
{[1.84]}\end{array}$ & & $\begin{array}{c}{[41.01]^{\star \star *}} \\
0.571 \\
{[49.68]} \\
{[2.38]}\end{array}$ & & $\begin{array}{c}{[47.72]^{\star \star \star}} \\
0.590 \\
{[57.74]} \\
{[3.27]^{\star}} \\
\end{array}$ \\
\hline Observations & 716 & 716 & 862 & 862 & 998 & 998 \\
\hline
\end{tabular}

Note: Standard errors, clustered at industry-city level, are reported in brackets. ${ }^{\star \star \star} p<0.01,{ }^{\star \star} p<0.05,{ }^{*} p<0.1$. 
Table 8, Role of financial institutions

\begin{tabular}{|c|c|c|c|c|c|}
\hline \multirow[b]{2}{*}{ Dependent Variable } & 1 & 2 & 3 & 4 & 5 \\
\hline & \multicolumn{5}{|c|}{ Value Added Ratio } \\
\hline Contracting Institutions & & & $\begin{array}{c}-0.047 * * \\
{[0.022]}\end{array}$ & $\begin{array}{c}-0.275 * * * \\
{[0.064]}\end{array}$ & $\begin{array}{c}-0.279 * * * \\
{[0.064]}\end{array}$ \\
\hline Contracting Institutions * External Finance Reliance & & & & $\begin{array}{c}0.265^{* * *} \\
{[0.071]}\end{array}$ & $\begin{array}{c}0.264^{* * *} \\
{[0.072]}\end{array}$ \\
\hline Financial Institutions & $\begin{array}{c}-0.001 \\
{[0.017]}\end{array}$ & $\begin{array}{l}0.103^{*} \\
{[0.061]}\end{array}$ & $\begin{array}{l}-0.003 \\
{[0.019]}\end{array}$ & $\begin{array}{c}0.115^{* *} \\
{[0.056]}\end{array}$ & $\begin{array}{c}0.104 \\
{[0.067]}\end{array}$ \\
\hline Financial Institutions * External Finance Reliance & & $\begin{array}{l}-0.110^{*} \\
{[0.068]}\end{array}$ & & $\begin{array}{c}-0.129 * * \\
{[0.062]}\end{array}$ & $\begin{array}{c}-0.130 * * \\
{[0.062]}\end{array}$ \\
\hline External Finance Reliance & & $\begin{array}{c}0.020 \\
{[0.030]}\end{array}$ & & $\begin{array}{c}-0.140^{* *} \\
{[0.057]}\end{array}$ & $\begin{array}{c}-0.139 * * \\
{[0.057]}\end{array}$ \\
\hline Contracting Institutions * Financial Institutions & & & & & $\begin{array}{c}0.016 \\
{[0.051]}\end{array}$ \\
\hline \multicolumn{6}{|l|}{ Firm Characteristics } \\
\hline Firm Size & $\begin{array}{c}0.001 \\
{[0.007]}\end{array}$ & $\begin{array}{c}0.002 \\
{[0.008]}\end{array}$ & $\begin{array}{c}0.004 \\
{[0.008]}\end{array}$ & $\begin{array}{c}0.006 \\
{[0.007]}\end{array}$ & $\begin{array}{c}0.006 \\
{[0.007]}\end{array}$ \\
\hline Firm Age & $\begin{array}{l}0.020^{*} \\
{[0.011]}\end{array}$ & $\begin{array}{l}0.026^{*} \\
{[0.014]}\end{array}$ & $\begin{array}{c}0.01 \\
{[0.011]}\end{array}$ & $\begin{array}{c}0.02 \\
{[0.014]}\end{array}$ & $\begin{array}{c}0.02 \\
{[0.014]}\end{array}$ \\
\hline Percentage of Private Ownership & $\begin{array}{c}0.01 \\
{[0.023]}\end{array}$ & $\begin{array}{c}0.003 \\
{[0.026]}\end{array}$ & $\begin{array}{c}0.013 \\
{[0.024]}\end{array}$ & $\begin{array}{c}0.011 \\
{[0.027]}\end{array}$ & $\begin{array}{c}0.011 \\
{[0.027]}\end{array}$ \\
\hline Degree of Computerization & $\begin{array}{c}0.076 * * \\
{[0.035]}\end{array}$ & $\begin{array}{c}0.051 \\
{[0.036]}\end{array}$ & $\begin{array}{c}0.057 \\
{[0.038]}\end{array}$ & $\begin{array}{c}0.034 \\
{[0.038]}\end{array}$ & $\begin{array}{c}0.035 \\
{[0.039]}\end{array}$ \\
\hline \multicolumn{5}{|l|}{ CEO Characteristics } & Human Capital \\
\hline Education & $\begin{array}{c}0.003 \\
{[0.003]}\end{array}$ & $\begin{array}{c}0.004 \\
{[0.004]}\end{array}$ & $\begin{array}{c}0.003 \\
{[0.004]}\end{array}$ & $\begin{array}{c}0.005 \\
{[0.004]}\end{array}$ & $\begin{array}{c}0.005 \\
{[0.004]}\end{array}$ \\
\hline Tenure & $\begin{array}{c}-0.002 \\
{[0.002]}\end{array}$ & $\begin{array}{c}-0.003 \\
{[0.002]}\end{array}$ & $\begin{array}{c}0.000 \\
{[0.002]}\end{array}$ & $\begin{array}{c}-0.002 \\
{[0.002]}\end{array}$ & $\begin{array}{c}-0.002 \\
{[0.002]}\end{array}$ \\
\hline Deputy CEO Before & $\begin{array}{c}0.006 \\
{[0.014]}\end{array}$ & $\begin{array}{c}0.006 \\
{[0.016]}\end{array}$ & $\begin{array}{c}0.009 \\
{[0.016]}\end{array}$ & $\begin{array}{c}0.011 \\
{[0.017]}\end{array}$ & $\begin{array}{c}0.011 \\
{[0.017]}\end{array}$ \\
\hline \multicolumn{6}{|l|}{ Political Capital } \\
\hline Government Cadre & $\begin{array}{c}-0.052 \\
{[0.050]}\end{array}$ & $\begin{array}{c}-0.075 \\
{[0.046]}\end{array}$ & $\begin{array}{c}-0.049 \\
{[0.051]}\end{array}$ & $\begin{array}{c}-0.077 \\
{[0.048]}\end{array}$ & $\begin{array}{c}-0.076 \\
{[0.048]}\end{array}$ \\
\hline Party Membership & $\begin{array}{c}0.033^{* *} \\
{[0.015]}\end{array}$ & $\begin{array}{l}0.027^{*} \\
{[0.016]}\end{array}$ & $\begin{array}{l}0.029 * \\
{[0.015]}\end{array}$ & $\begin{array}{l}0.029 * \\
{[0.016]}\end{array}$ & $\begin{array}{l}0.029^{*} \\
{[0.016]}\end{array}$ \\
\hline Industry-city Dummy & Yes & Yes & Yes & Yes & Yes \\
\hline Constant & $\begin{array}{c}0.760 * * * \\
{[0.059]}\end{array}$ & $\begin{array}{c}-0.02 \\
{[0.084]}\end{array}$ & $\begin{array}{c}0.081 \\
{[0.084]}\end{array}$ & $\begin{array}{c}0.119 \\
{[0.081]}\end{array}$ & $\begin{array}{c}0.121 \\
{[0.081]}\end{array}$ \\
\hline Observations & 1263 & 1075 & 1118 & 954 & 954 \\
\hline R-squared & 0.1454 & 0.1795 & 0.1626 & 0.2173 & 0.2174 \\
\hline $\mathrm{p}$-value for F-test & 0.0000 & 0.0000 & 0.0000 & 0.0000 & 0.0000 \\
\hline
\end{tabular}


Note: Standard errors, clustered at industry-city level, are reported in brackets. ${ }^{\star \star \star} p<0.01,{ }^{\star \star} p<0.05,{ }^{*} p<0.1$. 